\title{
Behaviors of Rural Structures during Destructive
}

\section{Earthquakes}

\author{
Cemal Eyyubov ${ }^{1}$, İsa Eyyubov ${ }^{2}$ and Mehmet Hasnalbant ${ }^{3}$ \\ 1. Department of Civil Engineering, Faculty of Engineering, Erciyes University, Kayseri 38010, Turkey; \\ 2. Azerbaijan Research Institute of Building Materials and Engineering Constructions, Baku AZ 10104, Azerbaijan; \\ 3. Department of Civil Engineering, Faculty of Engineering, Nuh Naci Yazgan University, Kayseri 38170, Turkey
}

\begin{abstract}
This article deals with the results of the research on the behaviors of the rural buildings made up of local materials during earthquakes. This article reveals the mechanical properties of masonry detected based on experimental research results on wall samples made of local materials such as mud bricks, clay and straw mixture, rubble stones and limestones cut in standard sizes. In addition, the constructive measures prepared for the earthquake resistance of rural structures and the application techniques of these buildings in common construction are also generalized in this article.
\end{abstract}

Key words: Rural structures, local materials, earthquake resistance, masonry mechanical properties, adherence stress strength, wood beams.

\section{Introduction}

Depending on social, cultural and usage conditions, modern buildings can also be classified as urban structures and rural structures. Urban construction rules have been developed in the developed and developing countries of the world in a level appropriate to the requirements of earthquake-resistant structure construction. In these countries, standards are being applied which make it necessary to accept the "building construction and design rules in earthquake zones" which are being updated over time. These standards generally include requirements for urban construction.

Rural construction, as it used to be, is still carried out with construction materials that can be found near the construction site. In addition, the buildings built by people who settled in the outskirts of the big cities of developing countries are no different from rural buildings. In these structures, mud brick, clay-straw mixture, rubble stones collected from river beds and broken off from the rocks, and limestones produced by

Correspondingauthor: Cemal Eyyubov, professor; research fields: steel structures, earthquake engineering, and structural dynamic. E-mail: ceyyubov@erciyes.edu.tr. cutting in standard sizes, are still used as masonry materials. The masonry is made of clay, lime, lime-cement and cement mortars with low strength. These building walls have great intensity, low strength and stability.

Accordingly, recommended masonry materials in the earthquake zones of many countries do not include clay-straw mixture, mud bricks and rubble stones in building construction and design standards for use in earthquake-resistant buildings [1].

The rural people who constitute $46 \%$ of the world's population ${ }^{1}$ do not have the financial and technical means necessary to create a living space in line with the contemporary earthquake specifications. In some countries which located on active earthquake zones significant part of the population live in rural areas: China (44\%), India (67\%), Iran (27\%), Turkey (27\%) and Azerbaijan (45\%). People living in the rural areas of underdeveloped countries are still obliged to carry out the construction of their living spaces with materials with low durability and high density.

The widespread destruction of buildings made of

\footnotetext{
${ }^{1}$ http://data.worldbank.org/indicator/SP.RUR.TOTL.ZS.
} 
mud bricks and rubble stones in rural areas due to the impact of many intense and medium-intense earthquakes such as Şamaxı (1902), Mesina (1908), China (1920), Tokyo (1923), Erzincan (1939), Ashkabad (1948), Erzincan (1992), Van (2011), Çanakkale and Adana (2017), has caused the loss of thousands of lives and massive loss of property. Similar destruction is also encountered in Latin America as well as Eastern and Middle-Eastern countries from time to time.

The results of engineering surveys on the impacts of destructive earthquakes have also shown that the structures with load-bearing walls bonded with

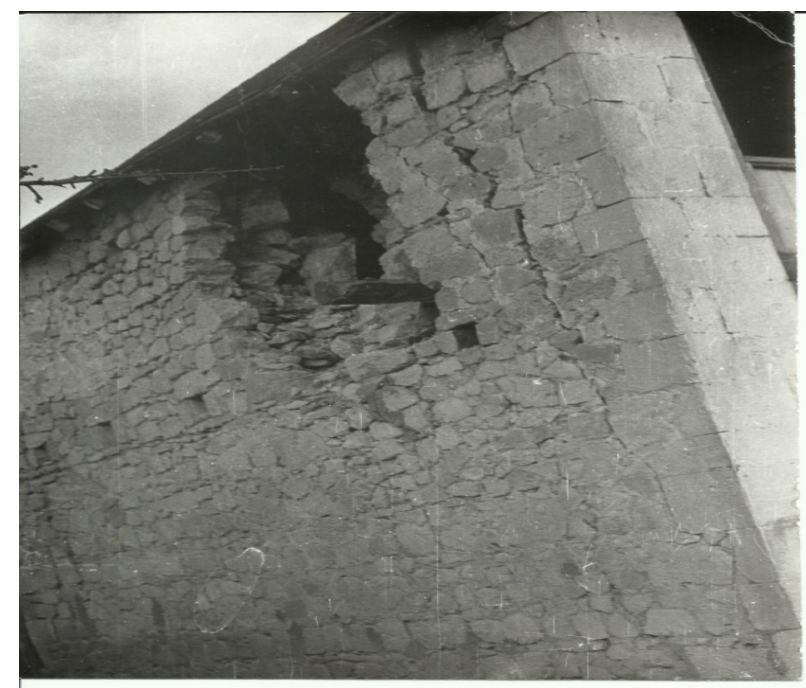

(a)

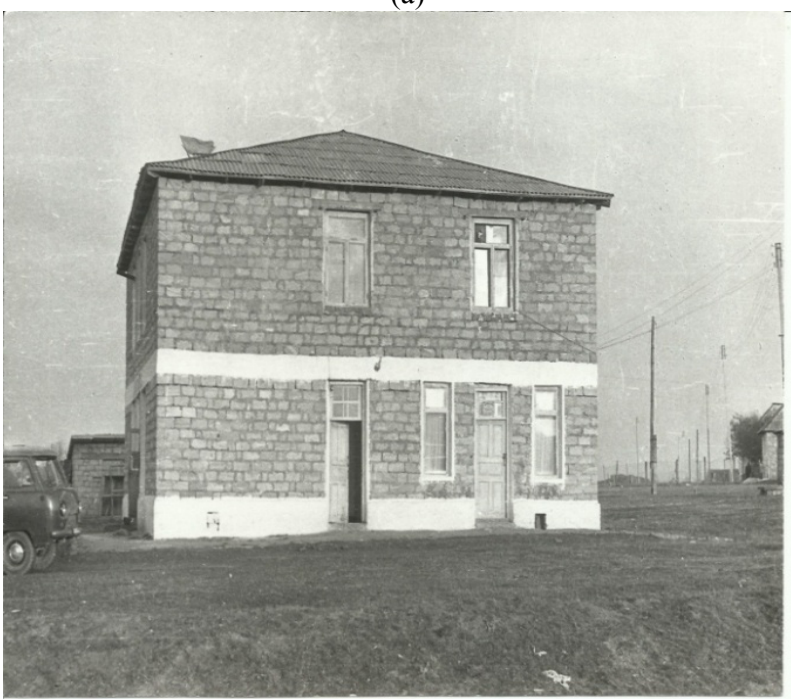

(c) materials with lower mechanical properties, such as mud bricks and rubble stones, and mortar with low mechanical properties exhibit different behaviors. Fig. 1 shows the post-earthquake appearance of two buildings (Figs. 1a and 1b) with level-4 damage according to MSK 64 due to the earthquake [2] with a magnitude of 5.4 and according to MSK 64 with level-7 surface impact, which occurred in 1981 in İsmayıllı region of Azerbaijan as well as two other buildings with level-1-2 damage according to MSK 64 with the same design properties close to the buildings above (Figs. 1c and 1d) [3].

Fig. 2 shows the multi-storey concrete building,

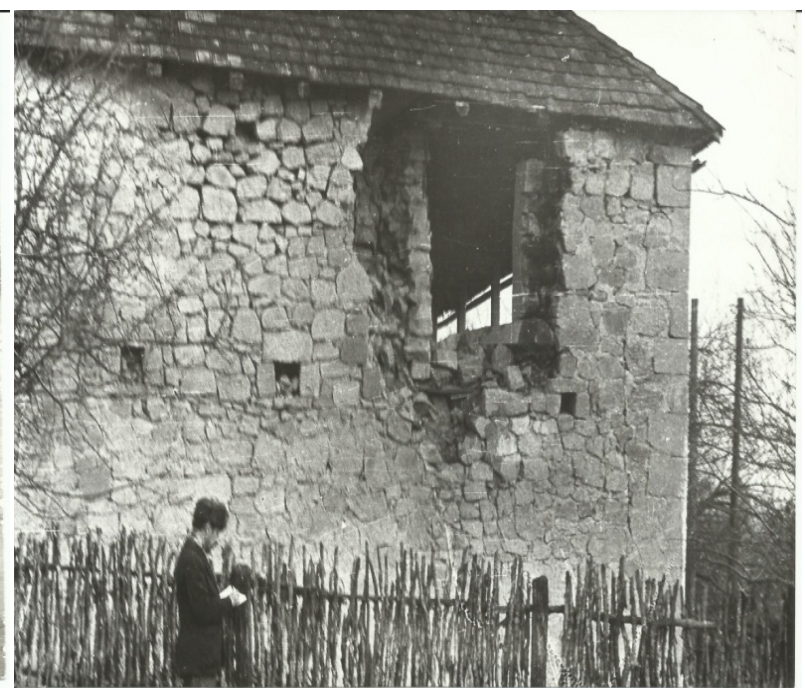

(b)

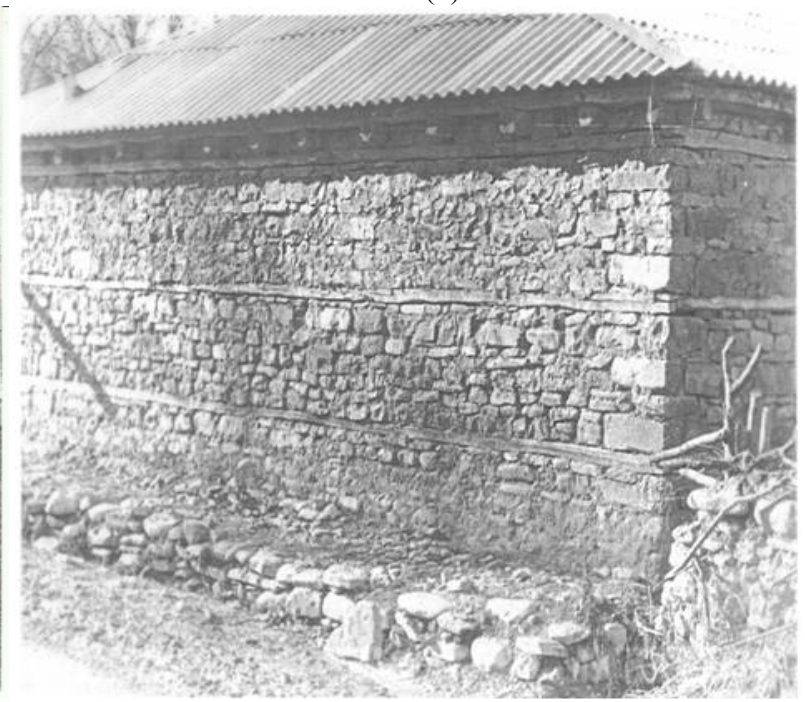

(d)

Fig. 1 Damaged buildings in the 1981 Ismayllı (Azerbaijan) earthquake: (a) Level 4 damaged building post-earthquake appearance; (b) Level 4 damaged another building; (c) Level 1-2 damaged building; (d) Level 1-2 damaged another building. 


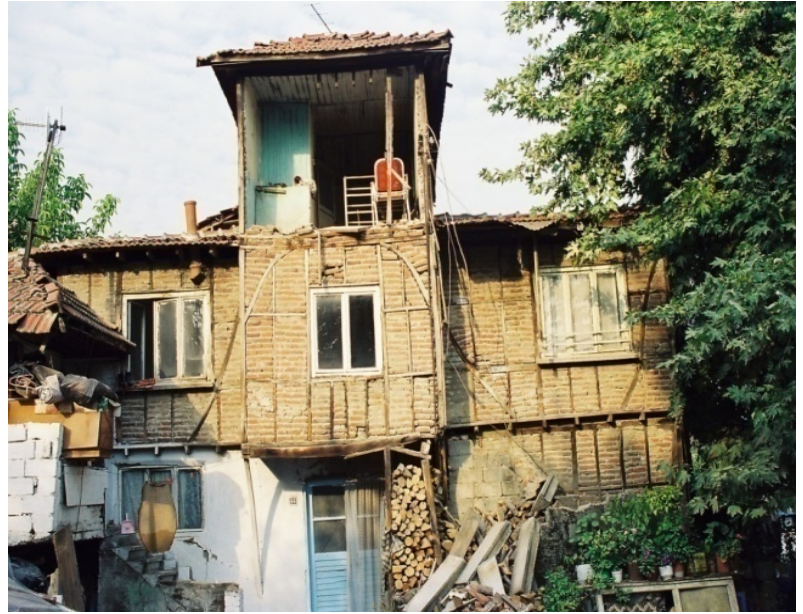

(a)

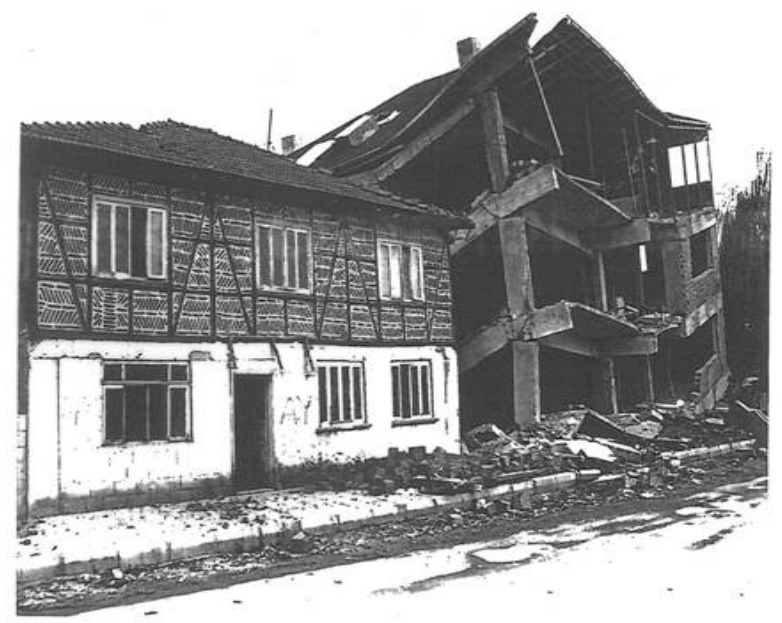

(b)

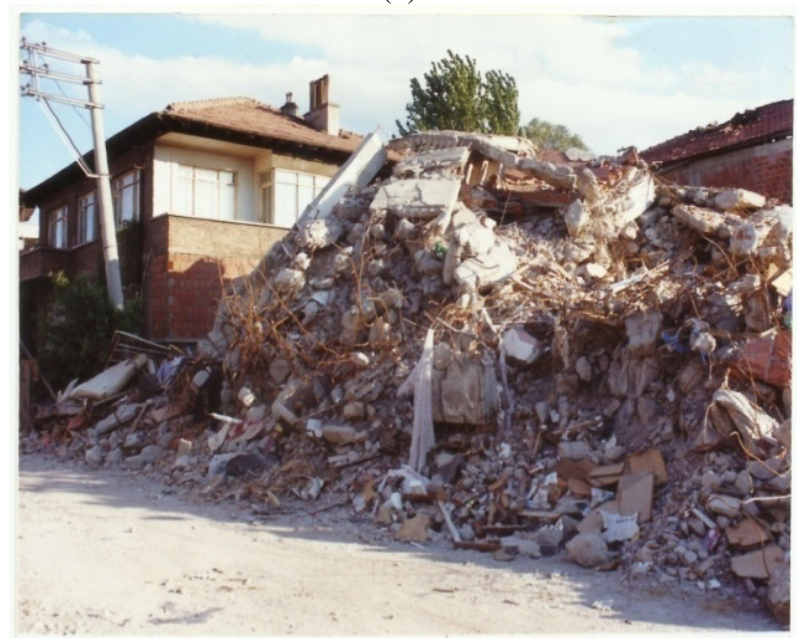

(c)

Fig. 21999 Kocaeli (Turkey) Earthquake damaged buildings: (a) wooden beams masonry building; (b) masonry and reinforced concrete buildings post-earthquake appearances; (c) masonry building and completely collapsed reinforced concrete building. constructed in line with the requirements of Regulations for the Structures to be Built in Disaster Areas [4, 5] in force between 1975-1998 in Turkey in an earthquake resistant design, with at least level-5 damage according to MSK 64 in the August and November earthquakes of 1999 with a magnitude of 7.4 which impacted İzmit-Düzce regions of Turkey as well as the 1-2-storey buildings right next to them (distance between the buildings is $3 \sim 5 \mathrm{~m}$ ) that were constructed without observing the contemporary earthquake specifications with brick and mud-brick masonry which survived this earthquake with level-1-2 damage according to MSK 64.

Similar events have also been observed in the results of engineering surveys of devastating earthquakes that have occurred in different countries of the world. The mosque structure made of wooden beams and rubble stones did not collapse while all the other buildings made of mud bricks, clay and rubble stones in the city collapsed with the impact of the earthquake that took place in Şamax1 city of Azerbaijan in 1902. This mosque structure was found to have 1-2 degrees of damage [6]. The same results were observed in the effects of the earthquakes that took place in Ashgabat (Turkmenistan) and Zakatala (Azerbaijan) in 1948 $[3,7]$. Medium-intense and destructive earthquakes that occur in the Caucasus, Central Asia, Iran, Anatolia and other regions of the Middle East, where the author participated in the engineering studies, showed that it is possible to construct earthquake-resistant buildings by using materials with low mechanical properties and high density such as mud bricks, clay-straw mixture, rubble stones if the appropriate constructive arrangements are applied.

In order to minimize the loss of life and property due to earthquake impact in rural areas, the following conditions must be met:

- Rural people must be convinced that it is possible to protect them from earthquakes and that human beings have the means for it;

- Simple constructive measures that can be made 
with tools and equipment (such as axes, hammers, saws, drills, scissors) that rural people have must be prepared and made available to these people;

- The technique for implementing these constructive measures should be simple and rural people should be trained in the application of the construction techniques of these constructs $[3,8]$.

The provision of such constructive measures and the preparation of application techniques are still relevant. The following are the constructive formations prepared in line with the demands of rural construction and the application techniques of these measures are given depending on the type of material used.

\section{Earthquake Resistance Measures in Rural Structures}

Masonry of the rural structures can be classified as mud brick-walls, clay-straw mixed walls, rubble-stone masonry, brick wall, limestone wall produced by cutting in standard sizes according to masonry material of rural buildings.

People living in the Caucasus, Central Asia, Anatolia, Iran and other Middle Eastern countries had the knowledge since the Middle Ages that earthquake is a threat to the structures which are not built earthquake resistant. The constructive measures implemented by rural people of these countries in the construction of the earthquake resistant building in the mid-ages had different characteristics depending on the building material. The characteristics and analyzes of the constructive measures determined from different written sources, from archaeological excavation research results, and from the examination and engineering researches of the buildings which survived up to this day are given below .

The evaluation of the earthquake resistance measures that the medieval architects and their masters prepared and the evaluation of the conditions under which these measures are prepared allow the preparation of qualified formations to respond to today's construction demands.

\subsection{Mud Brick and Clay-Straw Mixture Walled Buildings}

The clay-straw mixture is used in the construction of rural areas, produced as castable (monolith) and as mud brick. It is known from the results of engineering studies of these earthquakes that buildings made of mud brick masonry are destructed widely during devastating earthquakes, causing great loss of lives and property. However, the engineering study of the impact of earthquakes such as Samahı (1902), Kasımkent (1966), Ismayilli (1981), İzmit (1999) and Düzce (1999) showed that when the clay-straw mixture was used as the filling material for the wooden carcass, life and property loss due to earthquake impact was largely prevented [3, 9-12].

The constructional characteristics of a building type which is still in use and which is able to maintain its strength and stability during many earthquakes in Azerbaijan constructed by using clay-straw mixture are given in Fig. 3.

These buildings are constructed with basement and ground floor. The height of the basement floor is $1.5 \sim 2.5 \mathrm{~m}$ and its walls are made of rubble stones with a thickness of $0.50 \mathrm{~m}$ with cement, lime and clay mortar. The height of the ground floor is around $3 \mathrm{~m}$. The wall bearing system consists of wooden columns installed on the basement floor at every $1.5 \sim 2.5 \mathrm{~m}$ and a clay-straw mixture filled between them. The columns are enclosed in the horizontal frame considered at the top level of the basement. At the upper levels of the columns are the under-roof beams, which connect the wall of the building transversely and longitudinally and are connected safely with the columns. Columns are made of wood elements with a diameter of $20 \mathrm{~cm}$ or a cross-section of $15 \times 20 \mathrm{~cm}$. On both sides of the building wall, the columns are covered with wooden layer trussed with nails and the space between two wooden layers is filled with clay-straw mixture. Mud brick can also be used for this purpose. The clay-straw mixture is applied to both surfaces of the walls as the plaster layer. In the building bearing system constructed 


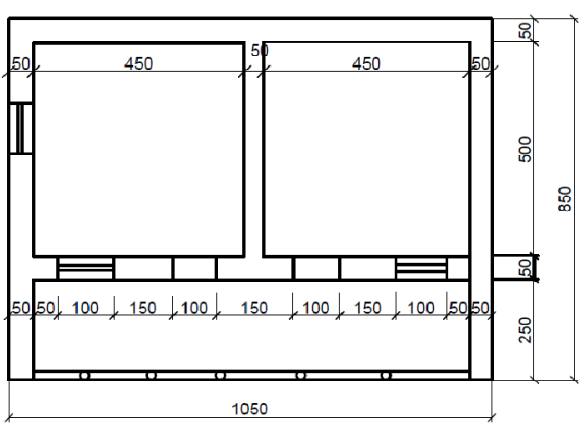

(a)
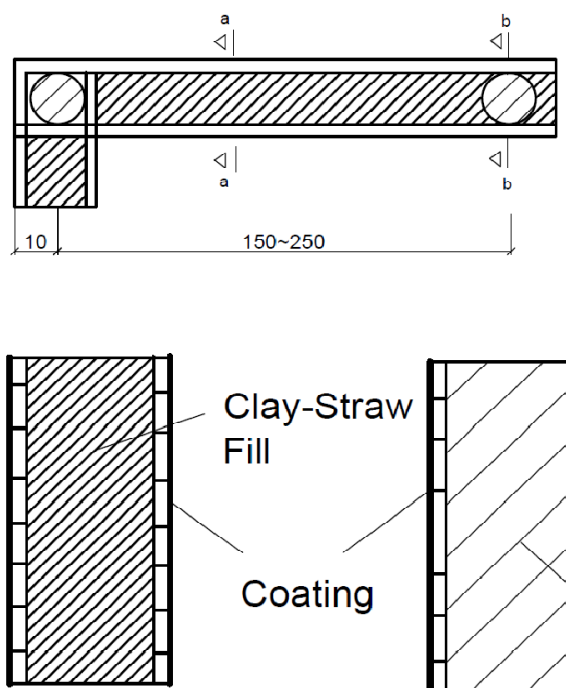

a-a Section

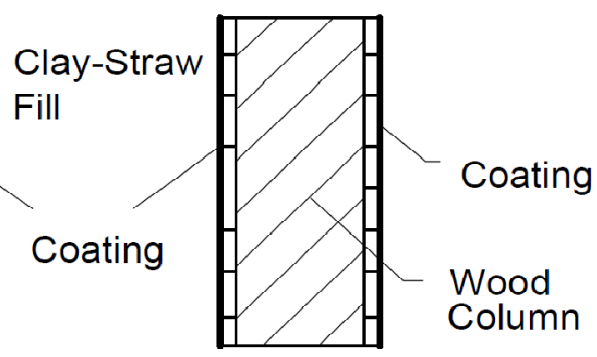

(c)

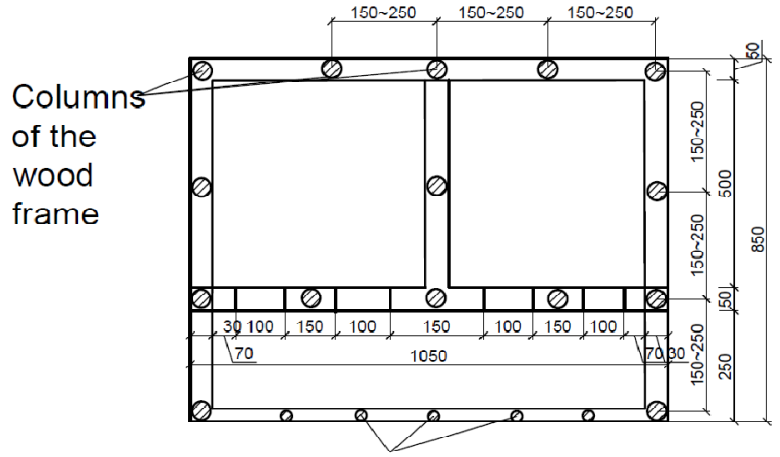

Balcony columns

(b)

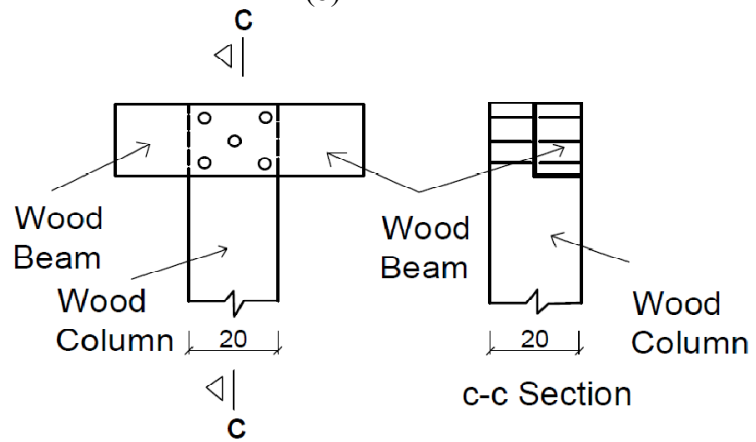

(d)

Fig. 3 Constructive formation of the building constructed by filling the carcass with clay-straw mixture: (a) the layout of the building; (b) constructive arrangement; (c) constructive formation of carcass; (d) formation of the column-beam intersection of the carcass.

by applying such a technique, wooden-carcass provides high strength and the clay-straw mixture or mud brick filled in the carcass provides the properties of killing the dynamic impact of the earthquake (swallowing the energy), which all together realize the formation of an earthquake resistant system $[3,7,9,11$, 13, 14]. The constructive formation of the wall cross-section is shown in Fig. 3c and the column beam intersection formation is shown in Fig. 3d.

We can characterize the reasons for the success of these constructive formations prepared by medieval masters (architects) as follows:
- Ensuring the usage of the high plastic deformation feature of clay as well as the elastic deformation and strength properties of the wood frame in this constructive order;

- The correct selection and acceptance of wooden frame geometric measures (distance between columns, column height, column and beam cross-sectional measurements) which ensure that the clay-straw mixture and the wooden frame work together under the earthquake impact;

- Selection and acceptance of suitable clay and wood type (kind). 
Theoretical and experimental investigation of the dynamic behavior of clay-straw mixture filled carcass structure is not given here since it is not within the scope of this article. In addition, these architects were able to implement measures to prevent the decay of wooden elements of the building walls and corrosion of the infilled wall material. Decay in the wood and corrosion in the elements of clay-filled walls are rarely encountered in these structures which survived up to this day.

\subsection{Buildings with Rubble Stone Walls}

The constructive plan design of the buildings made of rubble stones is as shown in Fig. 3a. It is carried out in two layers including the outer wall layer and the inner wall layer along the masonry height in the rubble stones applied in the rural areas. The masonry layers are not connected with each other. The connection is only possible with the possible adherence stress strength between the masonry mortar and rubble stone surfaces. Accordingly, these longitudinal masonry layers undergo transverse permanent deformation in case of eccentric loading of the wall [3]. This is schematically shown in Fig. 4.

This deformation character can also be observed under the influence of the static loads. Under earthquake impact, the internal walls are completely dissolved due to the accumulation of the pre-existing internal stresses in the wall with the external stresses. There are also cases where the outer layers of the outer walls collapse by the earthquake impact (Fig. 5b):

(1) Limit State 1: The masonry behaves like a full monolithic element against external factors; the masonry stones and masonry mortar work together and the masonry maintains its monolithic form (Fig. 4a);

(2) Limit State 2: In the middle part of the masonry cross section, cracks are formed in vertical direction between the longitudinal layers; and as the load value or load application time increases, these cracks develop in the longitudinal and vertical directions and this limit state ends with the separation of the masonry into layers (Fig. 4b). Furthermore, in this limit state, transverse deformations start to occur along the wall thickness;

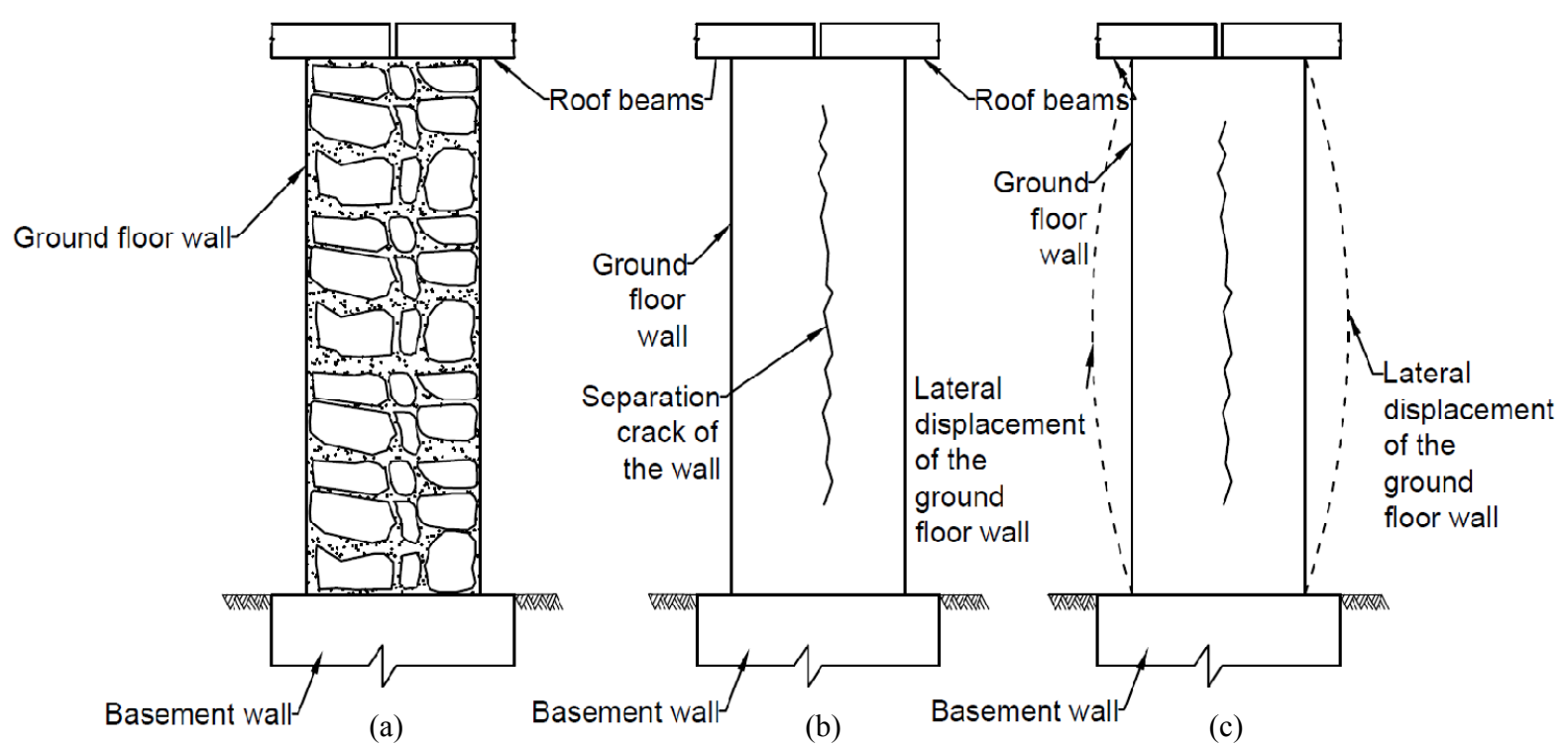

Fig. 4 Behaviors of rubble stone interior walls are: (a) the condition of providing masonry integrity; (b) the formation of cracks in the masonry separating into layers; (c) the formation of significant lateral deformations in the masonry (permanent deformation). 
(3) Limit State 3: In the middle part of the wall, a significant thickening is observed due to the transverse deformation, and this transverse deformation value decreases towards the upper and lower ends of the wall. No change in wall thickness is observed at the top and bottom ends of the wall (Fig. 4c);

(4) Limit State 4: In the middle part of the wall height, the transverse deformation rapidly develops and this becomes the starting point for the wall's dissolution. When the loading of the wall is stopped after the third limit state, the wall retains its stability for a certain period of time in this limit state. In the case of the 3rd limit state, if the loaded state of the wall is lengthened for a long time, the 3 rd state switches to the 4th limit state.

In case of loading the outer walls, the stairwell walls and the walls similar to those shown in Fig. 5a, the 3rd limit state does not take place; and by the end of the 2nd limit state, dissolution might occur as if at the 4th limit state (Fig. 5b).

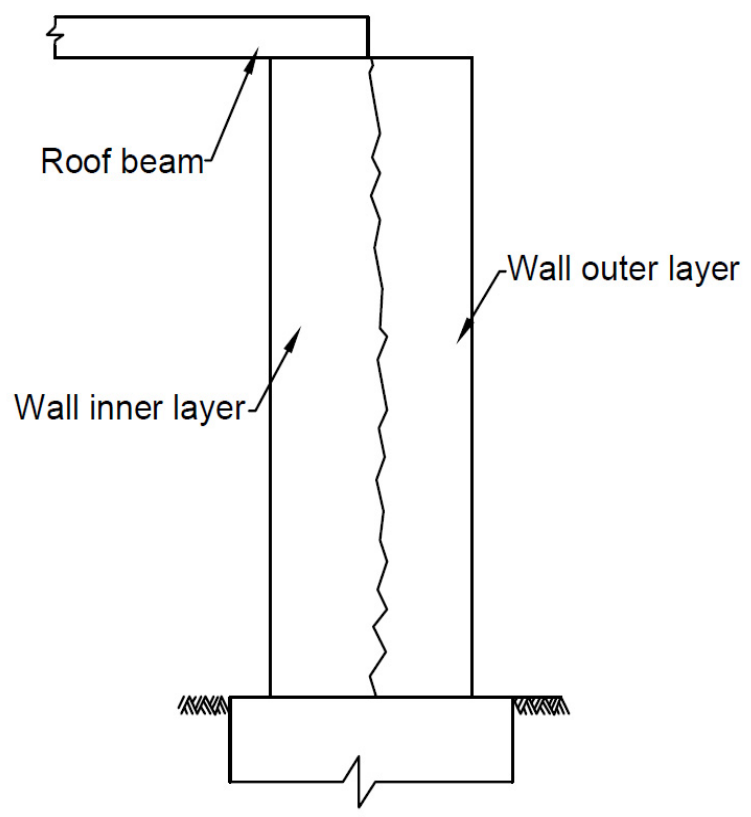

(a)
The following is the constructive formation based on the above-mentioned behavioral characteristic of buildings constructed with rubble stones and used in the earthquake resistant buildings in the past.

\subsection{Earthquake Resistance Measures in Masonry Made of Rubble Stones}

There are examples showing that the buildings built with rubble stones and wooden beams are standing for several centuries in the earthquake zones of Central Asia, Anatolia and Azerbaijan and that they have not collapsed during destructive earthquakes $[3,6,15]$. The constructive plan design of these buildings is as shown in Fig. 3a. Wooden beams are placed in the wall per $60-150 \mathrm{~cm}$, one being for the thickness and another for the height of the wall. In these buildings, the wooden beams prevent the masonry from separating into vertical layers and allow the supporting walls to work in transverse and longitudinal direction together (Fig. 6).

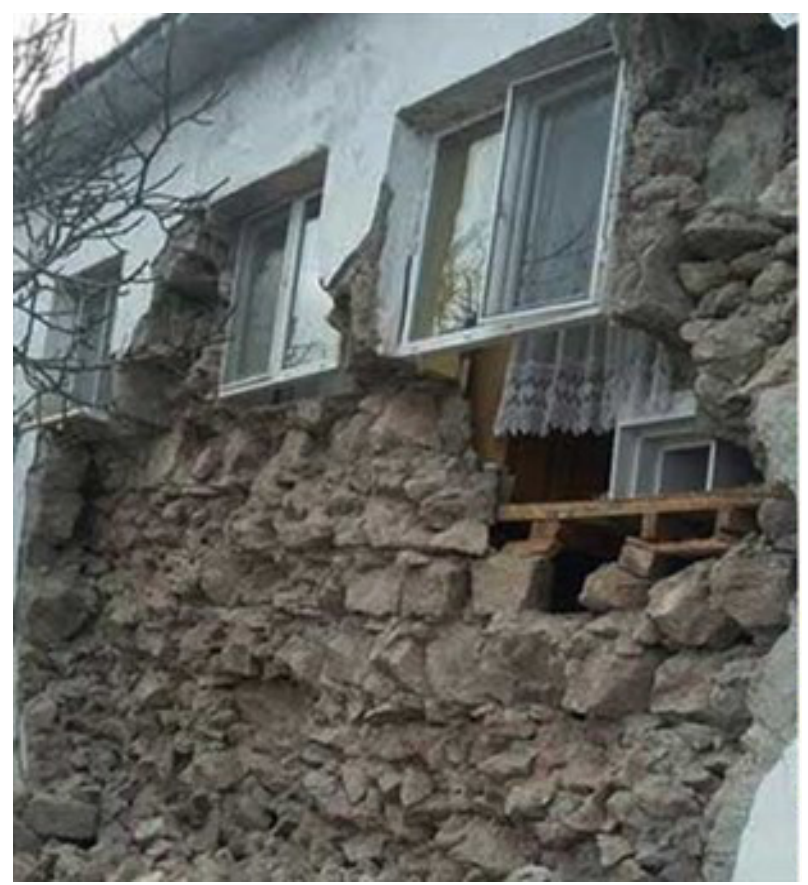

(b)

Fig. 5 Behavior of unilaterally loaded rubble stone walls, such as exterior walls or stairwells: (a) crack character; (b) dissolution of the outer layer during earthquake. ${ }^{2}$

\footnotetext{
${ }^{2}$ http://www.bigazete.com.tr/2017/2/artcilarin-arasinda-ikinci-buyuk-deprem-daha-51-h25511.
} 


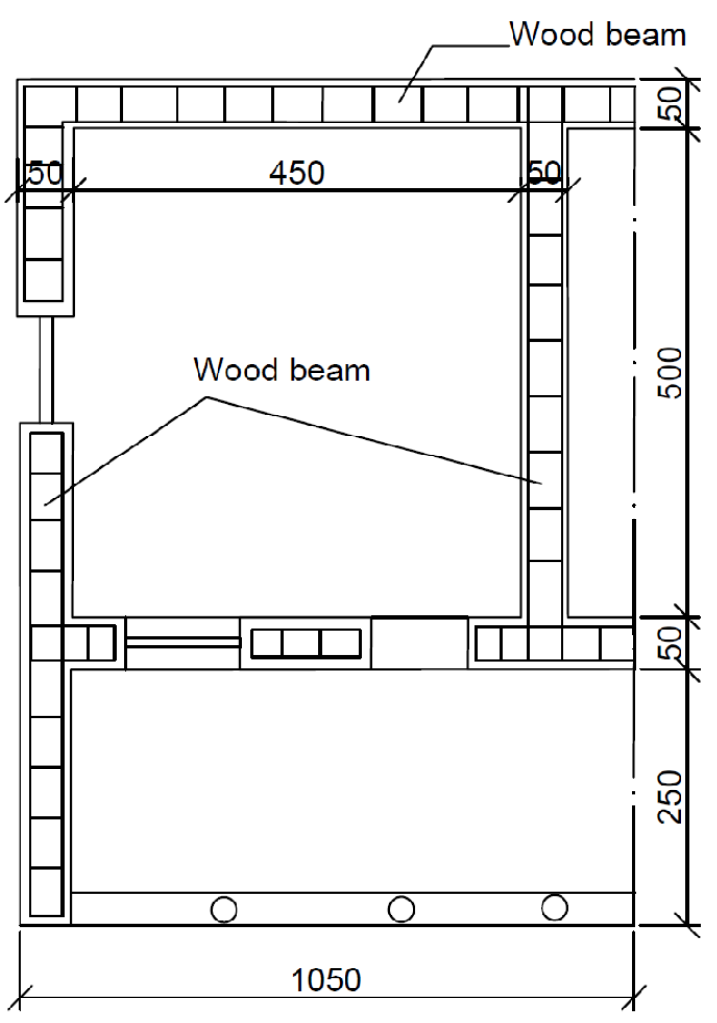

(a)

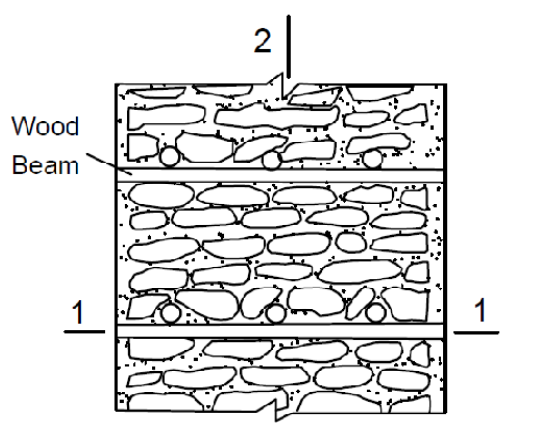

2-2

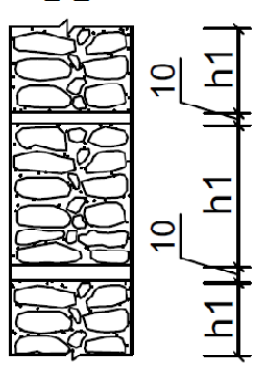

$2 \mid$

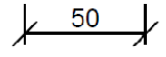

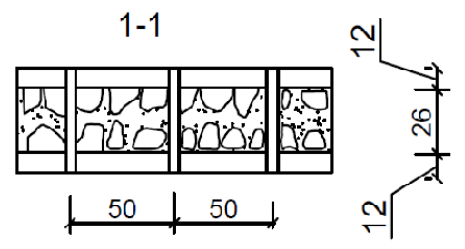

(b)

Fig. 6 Constructive system of rubble stone-walled buildings made by using wooden beams are: (a) placement of wooden beams at the building plan; (b) placement of wooden beams throughout the wall height (units in $\mathrm{cm}$ ).

Two principles were taken as basis for strengthening with wooden beams:

- Wooden beams must ensure continuity so that the walls of the building can be connected to each other transversely and longitudinally. These beams can be formed at the upper levels of the window openings, along the floor height and at different levels of the floor height;

- Wooden beams can be formed at every $h=$ $60 \sim 150 \mathrm{~cm}$ along the height of the building. The main task of these beams is to prevent separation of the walls of the building into layers by connecting the two longitudinal layers of the walls together; and to ensure that the walls of the building work together in longitudinal and transverse direction.

Here, wood was specially chosen as the material for the beam. The beams were selected from decay-resistant, high-strength dry wood materials. Oak trees were widely used for this purpose. There are examples in which the beams made of wood that does not comply with these conditions could not protect the building from the impact of earthquakes as a result of decay over time [3]. It is seen in the engineering survey of 1981 Ismayilli (Azerbaijani) earthquake that the wooden beams did not prevent the dissolution of walls with low strength masonry. In Fig. 7, it is observed that only the wall parts above and under the beam put in the middle of the floor height along the wall height dissolved due to the earthquake impact.

In addition, as seen in Fig. 7, the wooden beam considered at the middle of the height of the floor retained its previous state and did not detach due to earthquake effect. The examination of the masonry buildings made of wooden beams in earthquake zones showed that the distance between wooden beams is different in different wall types along the wall height. Detailed investigations have shown that the distance between beams along the wall height is around 


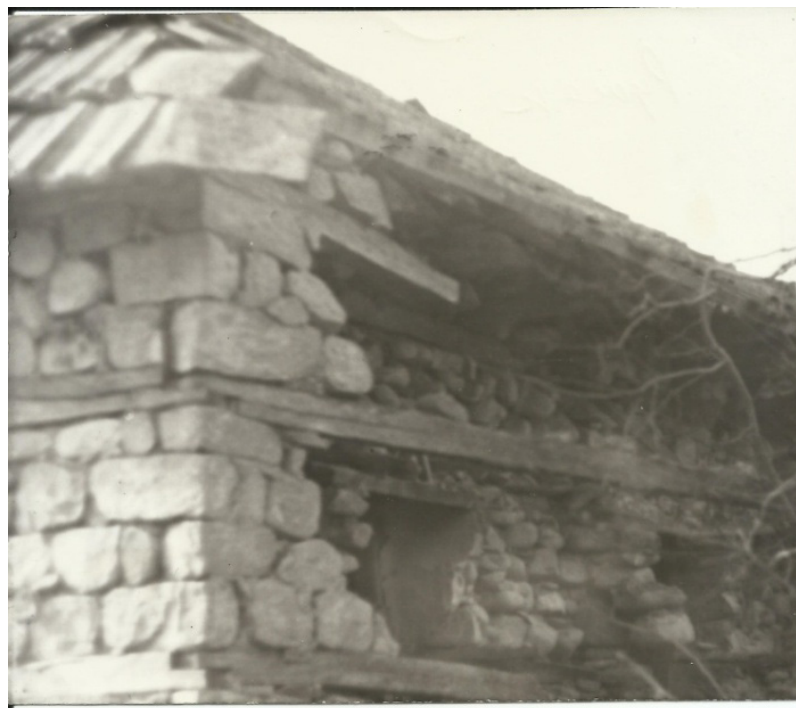

Fig. 7 A building where the distance between wooden beams is not suitable for masonry quality.

60 100 cm in walls bonded with mortar of clay-straw mixture and is around $120 \sim 150 \mathrm{~cm}$ in walls made of mortar of lime or lime-cement mixture. Thus, these architects changed the distance between the beams along the height, depending on the strength of the masonry. They considered this distance as far in the walls with high strength, and as short in the walls with low strength. When this principle deteriorated, serious damage to the masonry was observed (Fig. 7).

Moreover, the widespread use of wooden beams in today's rural construction is not possible in some countries. The selection of wood materials that can be used for this purpose and the application of antiseptic measures are costly. The preparation of simple constructive measures that can be carried out with less cost that can be applied in the construction of rural areas and the development of techniques for widespread construction application are still relevant issues.

\subsection{Strengthening Construction of Rubble Stone Masonry}

Strengthening of stone and brick masonry with reinforcement is widely used in the construction of earthquake resistant buildings. Buildings with masonry supported by reinforcement behaved better during earthquakes in southern California and India $[6,15,16]$. It is known that reinforced concrete beams used at floor levels are also inspired by the wooden beam formations used in rubble stone masonry walls in the past. In many standards in the world today, it is recommended to apply reinforced concrete beams at floor levels in brick and properly cut limestone walls $[1,5]$. However, in the researches after Aşkabat (1948), Tashkent (1966), Siyazan (1963), Gasımkent (1966), Dimanis (1978), Ismayilli (1981), Erzincan (1992) and other earthquakes, it has also been observed that there are numerous damages and demolitions in the masonry walled buildings formed with reinforced concrete beams at floor levels. It has been observed that there are no cracks in the reinforced concrete beams at the floor level, although the cracks covering the entire cross section of the wall diagonally and like a plus shape were formed in the space between the walls due to the impact of Siyazan earthquake (1963) $[3,7,13]$. The same behavior was observed during Erzincan (1992) earthquake at numerous brick-walled one and two storied buildings built in Üzümlü village. Here, although the basement and first floors of the buildings completely collapsed, cracks were not found in the reinforced concrete beams at the floor level (Fig. 8).

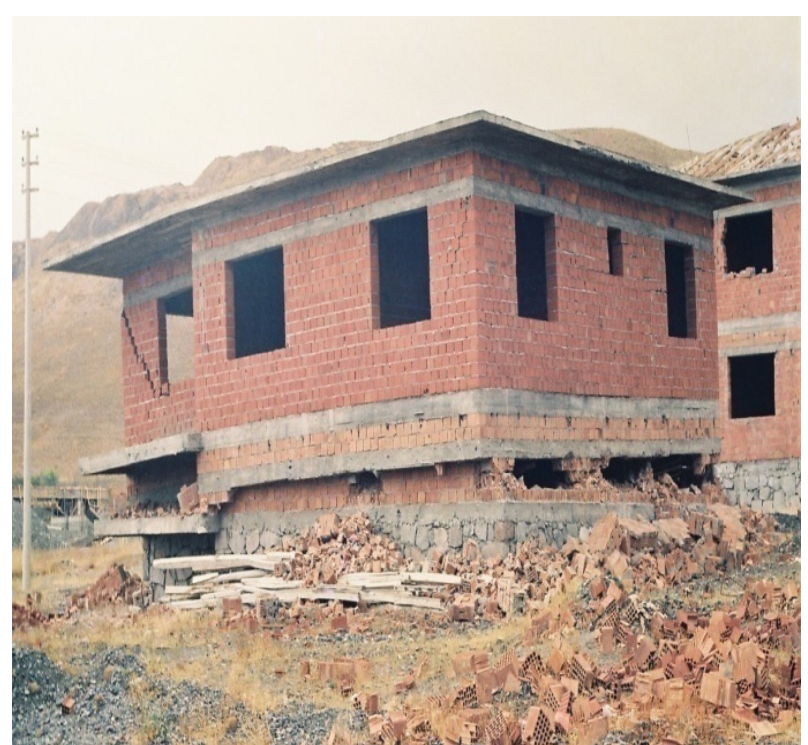

Fig. 8 Complete crushing and dissolution of the ground floor of a two-storey building with a concrete beam at the floor level. 
Thus, the concrete beams formed at the floor levels exhibited different behaviors during the earthquake. The beams formed at floor-level in quality walls formed with high-strength materials increased the earthquake resistance of the walls, and when materials with low mechanical properties are used in the walls, the walls collapsed as shown in Fig. 8.

In order to increase the earthquake-resistance of the masonry of stone and brick walled buildings, the wall must be normally reinforced with reinforcing bar or mat on the expected cracking planes of the wall. Depending on the classification of cracks on stone and brick walled buildings [3], the supporting walls must be reinforced by cutting the cracking plane in the vertical and horizontal directions in the masonry system. In general, reinforcement of the wall in the normal direction to the cracking plane can increase the strength of the masonry more effectively. However, reinforcement to be made with such formation is not used since it is difficult and complicated from the application and technical point of view. Vertical reinforcement in masonry is also complicated; thus, horizontal reinforcement is widely applied in practice. Since the prevention of corrosion of the reinforcement in the masonry seams requires complicated and additional cost on the external walls, strengthening of the reinforcement should be done with reinforced concrete elements rather than placing the reinforcement directly into the mortar. However, it is wrong to think that the earthquake resistance can be increased with reinforced concrete beams planned at the floor height of stone and brick walled buildings. Because the cross-sections of these beams remain outside some of the expected crack formation planes of the building walls. In the masonry at floor-levels of stone and brick-walled buildings, reinforced concrete beams that horizontally cut the crack formation planes expected on the walls increase the strength and stability of the masonry. The spacing of these beams along the floor height can be determined depending on the masonry strength. For low-strength masonry, the distance between the beams is less along the height of the wall, and more for high-strength masonry. The constructive formations of reinforced concrete beamed rubble stone masonry are given in Fig. 9 [9].

The spacing of reinforced concrete beams along the wall height can be determined depending on the strength and deformation capacity of the masonry by thickness, reinforcement cross section area and concrete class experimental methods. The results of the research carried out in the Earthquake Engineering Laboratory of Azerbaijan Institute of Construction and Architecture are given in Fig. 9.

\subsection{Investigation of Strength and Deformation of Rubble Stone Masonry}

2.5.1 Experimental Research Method of Strength and Deformation of Rubble Stoned Masonry Samples

In the research to determine the optimum values of the mechanical properties of the rubble stone masonry and the spacing between the beams at floor height, 4 series of masonry samples with a thickness of $50 \mathrm{~cm}$, a width of $100 \mathrm{~cm}$ and heights of 80, 100, 120 and 140 $\mathrm{cm}$ were prepared (Fig. 10).

A reinforced concrete layer with a thickness of 50 $\mathrm{mm}$ is considered at the top and bottom ends of each sample. Reinforcement of the reinforced concrete layer was carried out with stirrups with $2 \Phi 12$ longitudinal and $200 \mathrm{~mm}$ spacing and diameter of $\Phi 8 \mathrm{~mm}$. The reinforcement mat is made of ribless reinforcement bars of reinforcement class S220. Strength values of stone and mortar were determined according to the test results of cube samples taken from the sample masonry stones at the size of $100 \times 100 \times 100 \mathrm{~mm}$ and from the masonry mortar at the size of $70 \times 70 \times 70 \mathrm{~mm}$. Masonry samples were prepared using stones with a cube strength of $8 \mathrm{kN} / \mathrm{cm}^{2}$ and a mortar with a strength of $1.52 \mathrm{kN} / \mathrm{cm}^{2}$. The samples were prepared using the masonry technique used in the construction of real buildings. After the samples were prepared, they were watered twice a day (morning and evening) for 14 days. Experiments were carried out after the prepared masonry 

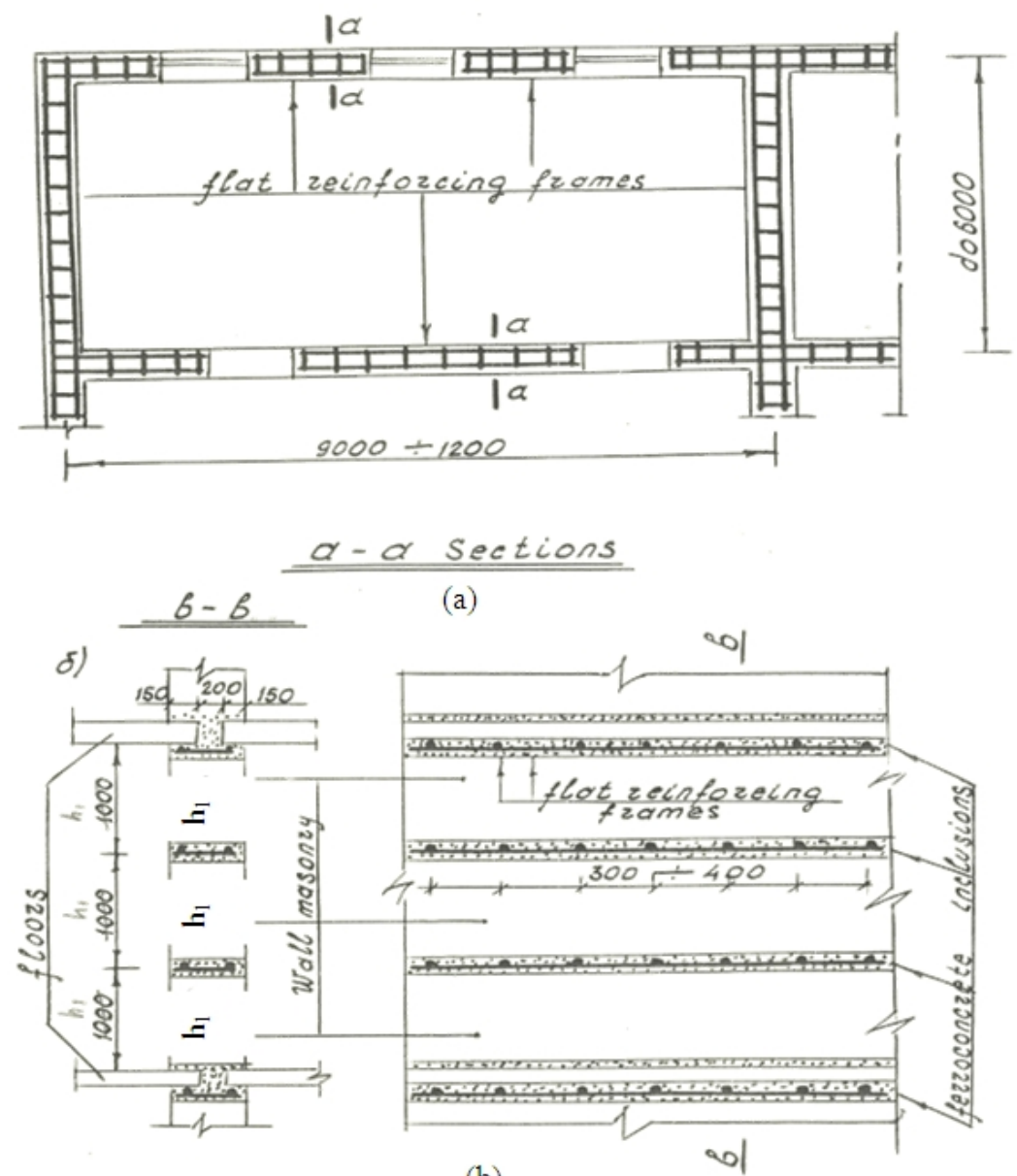

(b)

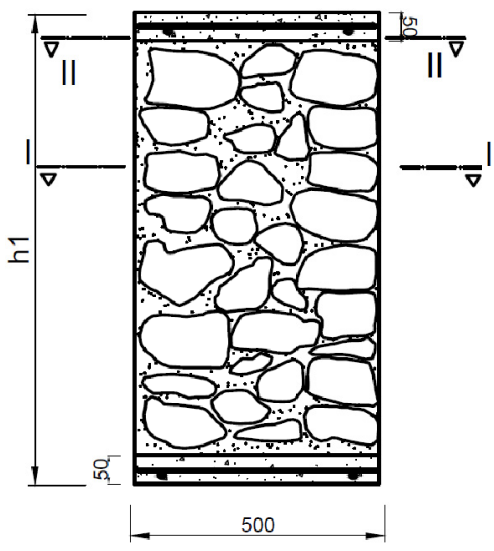

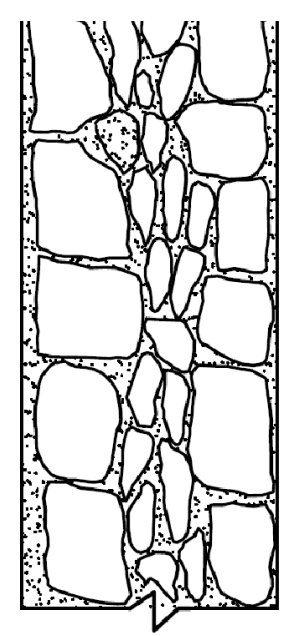

I-I

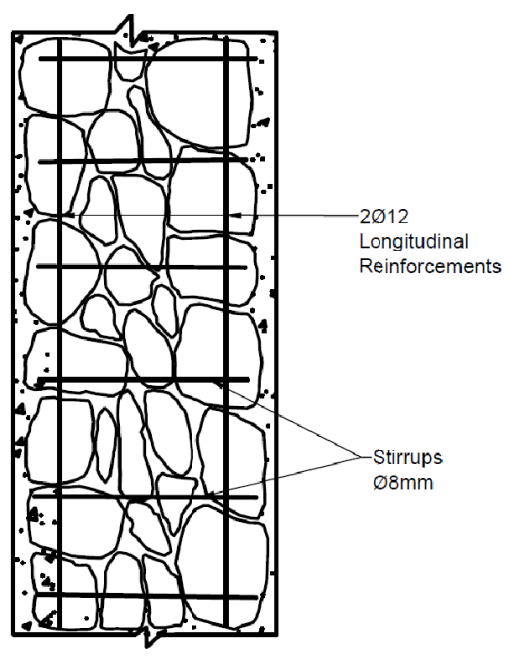

|I-II

(c)

Fig. 9 Reinforced concrete beamed rubble stone walled building construction formation: (a) plan design of the constructive system of the building; (b) the placement of the beams at the height of the building; (c) detail of beamed masonry. 
1. Serial

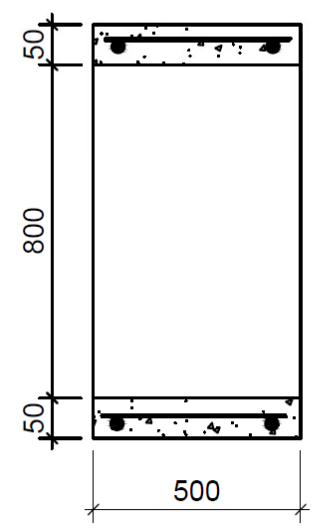

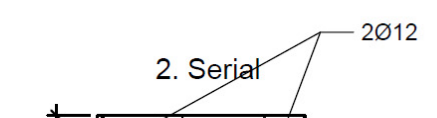

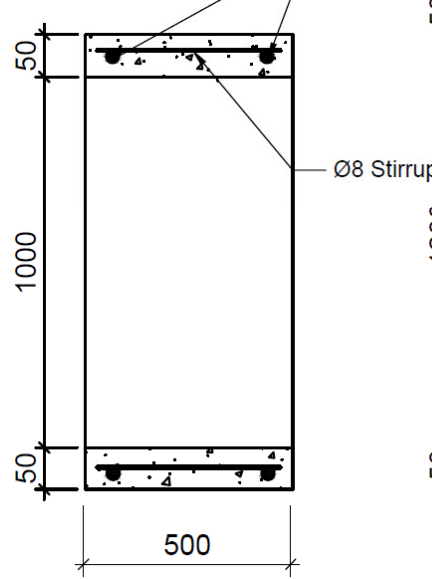

3. Serial

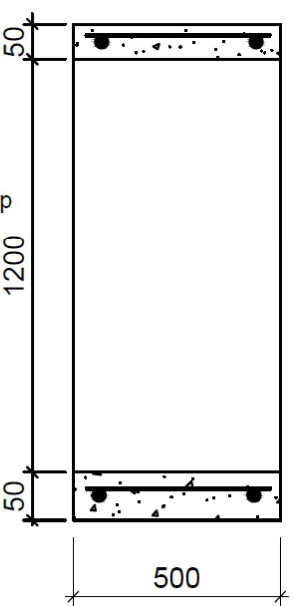

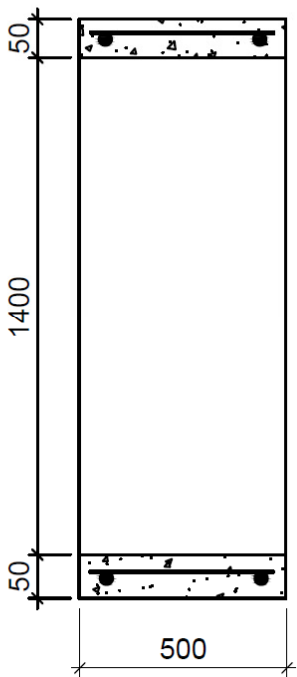

Fig. 10 Geometric measurements of the samples (mm).

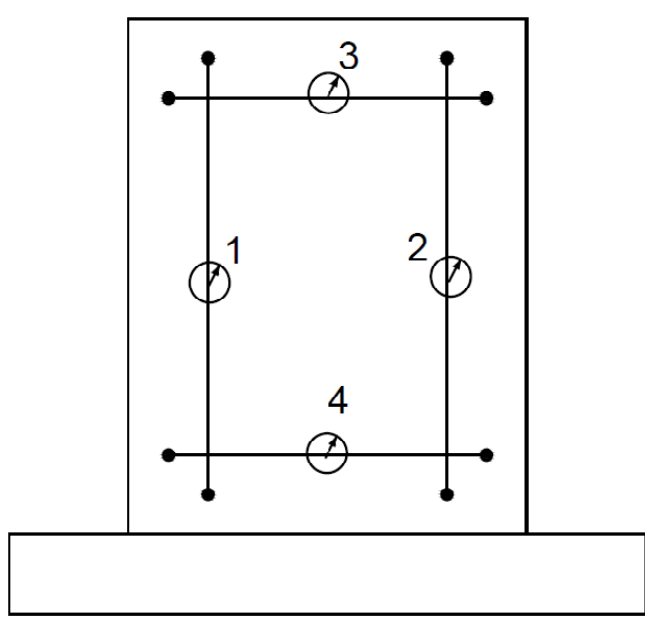

(a)

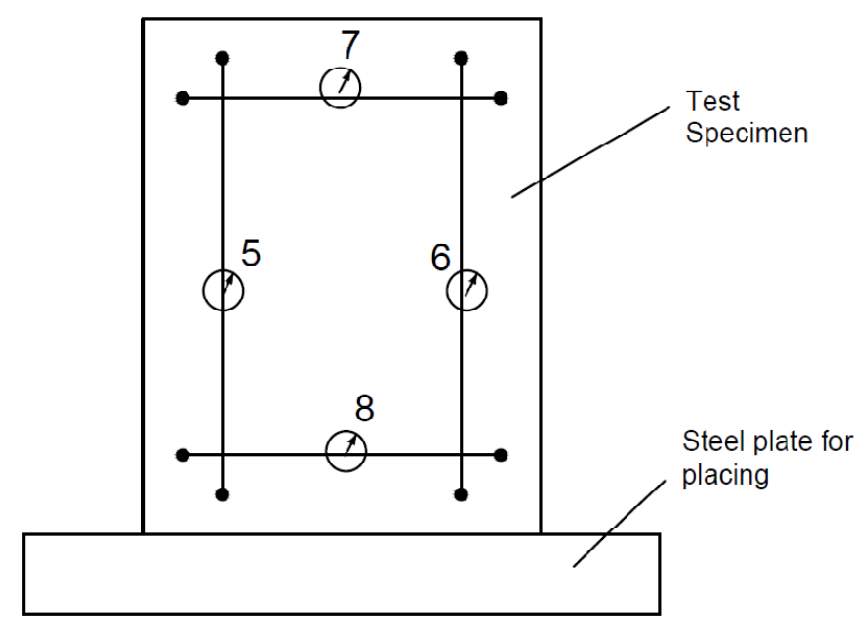

(b)

Fig. 11 Setting up the measurement devices: (a) placement of measurement devices on one side of the sample; (b) placement of the measurement devices on the other side.

samples rest for 28 days. Experiments were carried out with hydraulic press of 500 ton pressure capacity. It has been determined that load measurement error of the loading unit this press does not exceed $1 \% \sim 2 \%$. The vertical and horizontal deformations of the samples due to the load increase were measured with $0.001 \mathrm{~mm}$ precision clock-type deformation meters. The layout of the measurement devices in the samples is shown in Fig. 11.

For the samples, the load was applied increasingly with loading steps equal to $10 \%$ of the load capacity. After waiting for $5 \mathrm{~min}$ after each loading step, the deformation measurements were made.

The adherence stress between the masonry mortar and the stone was determined by specially prepared test setup. A piece of flat surface less than $100 \mathrm{~mm}$ in diameter is collected from the surface of the rubble stone. A plastic ring with an inner diameter of $100 \mathrm{~mm}$ and a height of $10 \mathrm{~mm}$ is placed in this area. The ring is filled with mortar. At the end of 28 days, a steel circular 
plate with a holder is glued on the mortar surface with epoxy. After the adhesive dries, this steel plate is normally put with the stone on the adhesion surface. Tensile strength is measured by the approach used on the scales.

2.5.2. Experimental Results of Strength and Deformation of Wall Rubble Stoned-Masonry Samples

In the results of the experiments made to determine the adherence stress between the mortar and rubble stone surface, it was observed that adherence stress is $0.014-0.023 \mathrm{kN} / \mathrm{cm}^{2}$ when the mortar strength is 0.24 $\mathrm{kN} / \mathrm{cm}^{2}$; when the mortar resistance is $0.48 \mathrm{kN} / \mathrm{cm}^{2}$, the adherence stress is $0.034-0.038 \mathrm{kN} / \mathrm{cm}^{2}$; and when the mortar strength is $0.63 \mathrm{kN} / \mathrm{cm}^{2}$, the adherence stress is $0.037-0.044 \mathrm{kN} / \mathrm{cm}^{2}$. The diagram of the relation between the mortar strength and the adherence stress is shown in Fig. 12, and the cracking characteristics of the samples during the experiment are shown in Fig. 13.

Adhesive tensile strength of natural rubble stone surface with mortar was assumed to be $15 \%-20 \%$ more than adherence tensile strength of detached rubble stone surface with mortar (Fig. 12) [17].

The difference between the adherence tensile strength of rubble stone surface detached with mortar and the adherence tensile strength of rubble stone surface in its natural state can reach up to $30 \%$.

The statistical analysis of the results of the experimental research showed that there is a connection as:

$$
\tau_{d}=3 \sigma_{a d}
$$

between the rubble stone surface and the mortar adherence stress strength and the shear stress strength along the same surface. The same results [18] were also found in the source.

Experiments on masonry samples made of rubble stones have shown that the strength of the sample decreases as the sample height increases. Such that, the rupture strength of the sample with a height of $80 \mathrm{~cm}$ is $1.25 \mathrm{kN} / \mathrm{cm}^{2}$ and strength in crack formation is 0.450 $\mathrm{kN} / \mathrm{cm}^{2}$; the rupture strength of the sample with a height of $100 \mathrm{~cm}$ is $1.12 \mathrm{kN} / \mathrm{cm}^{2}$ and strength in crack formation is $0.325 \mathrm{kN} / \mathrm{cm}^{2}$; the rupture strength of the sample with a height of $120 \mathrm{~cm}$ is $0.68 \mathrm{kN} / \mathrm{cm}^{2}$ and strength in crack formation is $0.21 \mathrm{kN} / \mathrm{cm}^{2}$; and the rupture strength of the sample with a height of $140 \mathrm{~cm}$ is $0.6 \mathrm{kN} / \mathrm{cm}^{2}$ and strength in crack formation is $0.2 \mathrm{kN} / \mathrm{cm}^{2}$. It was observed that the proportional deformation value increased with the sample height (Fig. 14).

The connection between sample height and rupture strength of the masonry is given in Fig. 15.

The increase of the sample height from $80 \mathrm{~cm}$ to $100 \mathrm{~cm}$ according to this diagram reduced the rupture strength of the sample by $10.4 \%$. Raising the sample height from $100 \mathrm{~cm}$ to $120 \mathrm{~cm}$ caused the rupture strength of the sample to decrease by $39.3 \%$. In addition, it is seen from the diagram that increasing the sample height from $120 \mathrm{~cm}$ to $140 \mathrm{~cm}$ causes the masonry strength to decrease by $11.76 \%$.

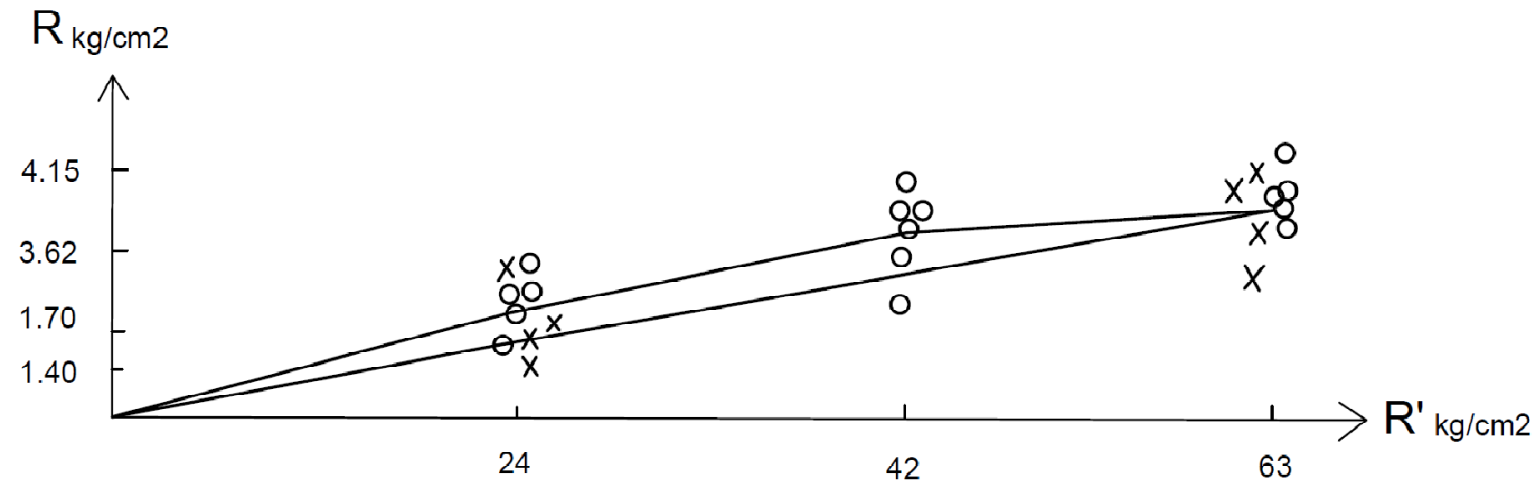

Fig. 12 The connection between the mortar strength and the adherence tensile strength on the rubble stone surface (o: on natural stone surfaces; $x$ : on the surface of detached rubble stone). 


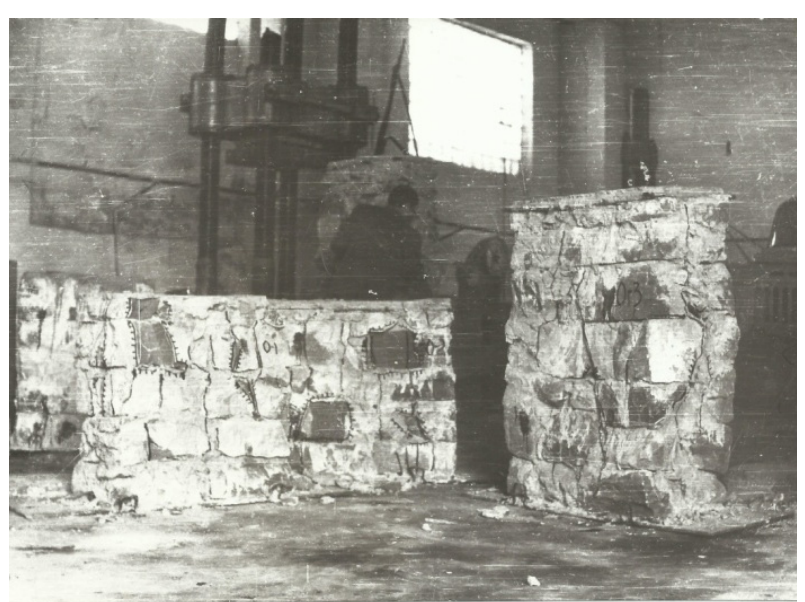

Fig. 13 Cracking characteristics of rubble stone samples during the experiment.

Thus, it can be assumed that the difference between the rupture strengths of samples up to $100 \mathrm{~cm}$ in height is up to $10 \%$. It can be assumed that these samples are not separated into layers until the rupture limit of the load application. Increasing the sample height up to $120 \mathrm{~cm}$ indicates that the separation of the masonry into layers has improved rapidly. Increasing the masonry height by more than $120 \mathrm{~cm}$ caused the sample to start to work as two layers. Accordingly, increasing the sample height from $120 \mathrm{~cm}$ to $140 \mathrm{~cm}$ reduced the rupture strength of the masonry by only $11.76 \%$. The same results can be seen by comparing the strengths of the samples according to the crack formation limit. Thus, it can be assumed that the optimal value of the distance between the beams is $100 \mathrm{~cm}$ when the rubble strength is $8 \mathrm{kN} / \mathrm{cm}^{2}$ and the mortar strength is $1.52 \mathrm{kN} / \mathrm{cm}^{2}$ according to the results of the experiment.

As the height of the samples increased, the crack
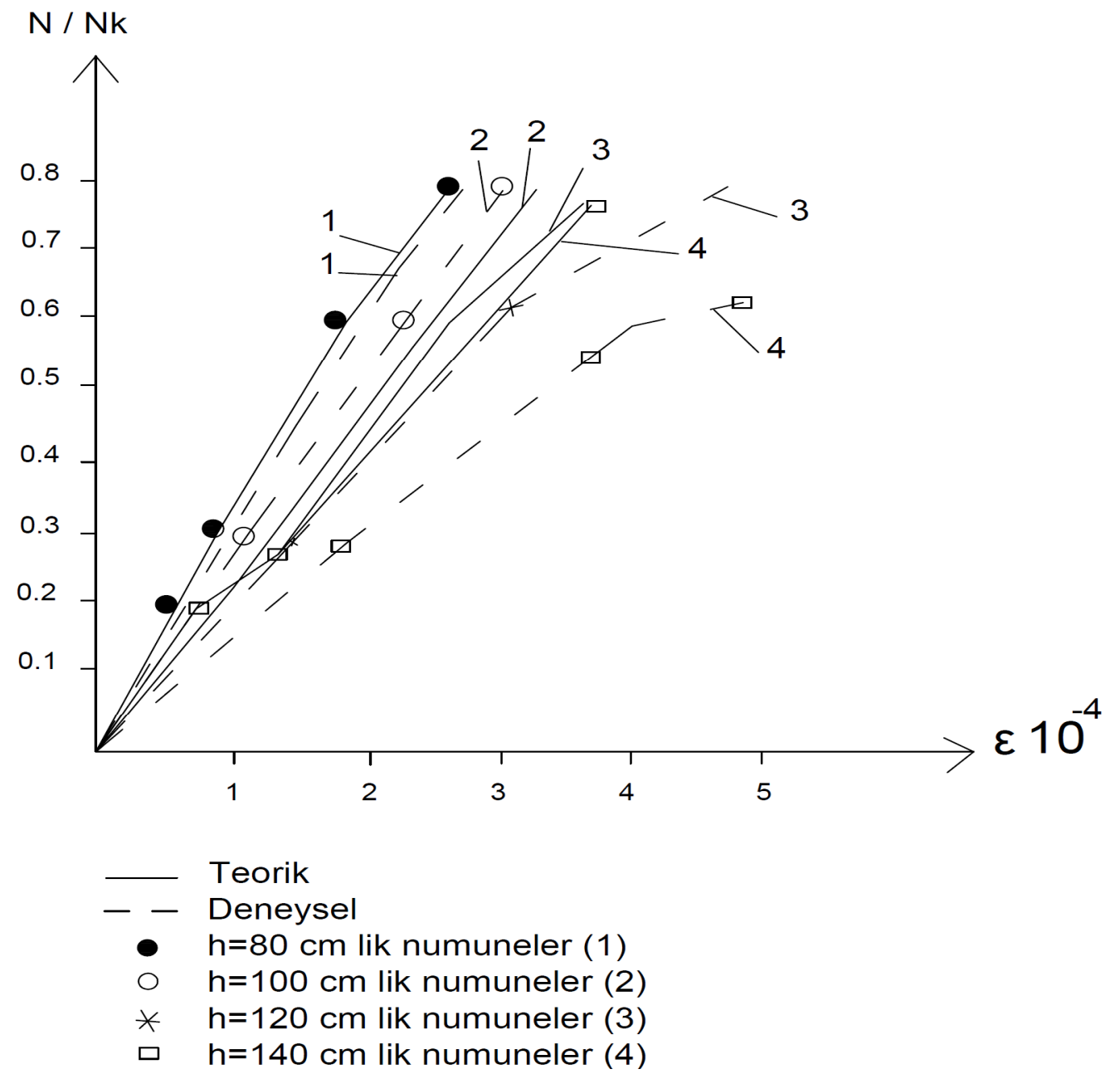

Fig. 14 Diagrams of $f\left(\varepsilon, N / N_{k}\right)$ depending on sample height. 


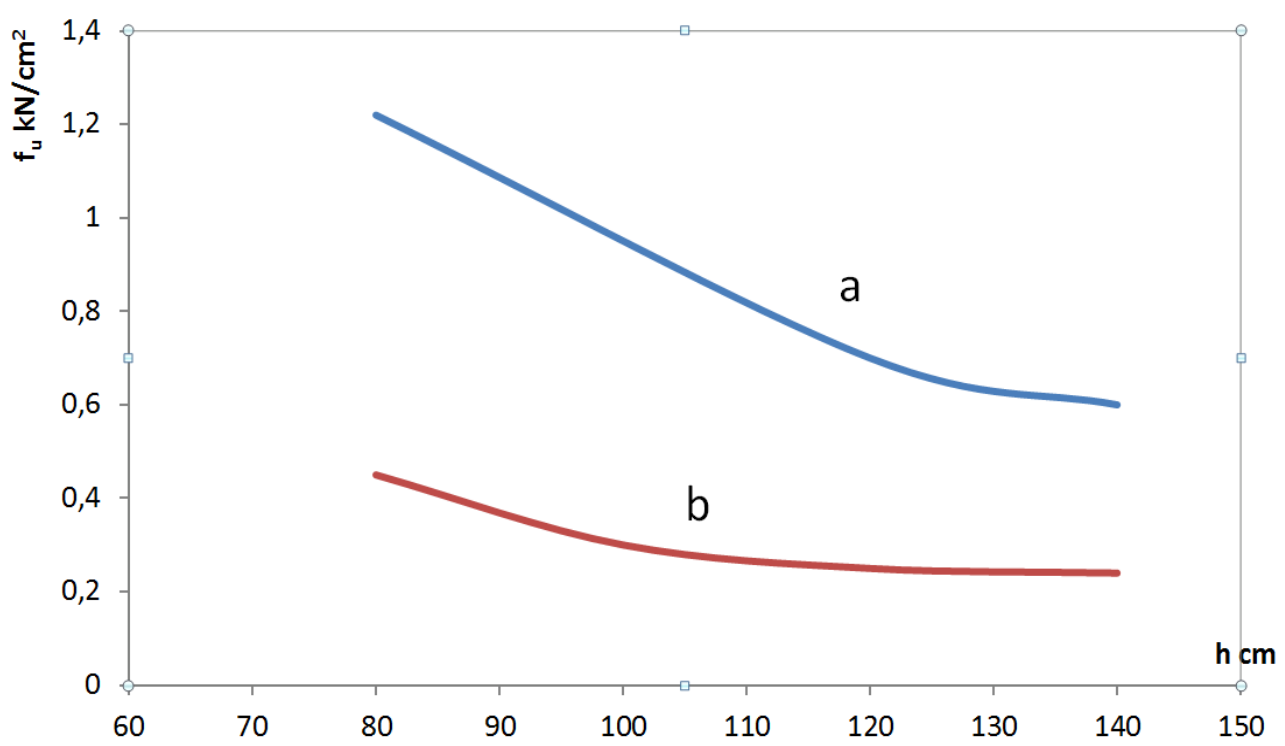

Fig. 15 The variation of the strength of the experiment samples depending on the height is: (a) suitable for rupture; (b) suitable for crack formation limit.

formation and the deforming properties changed. By increasing the height of the sample by $100 \mathrm{~cm}$, the strength of the crack formation was decreased by $28 \%$, while the increase in the height of the sample up to $120 \mathrm{~cm}$ led to decrease in the strength according to crack formation limit up to $55 \%$. This can be explained by three limit conditions that are clearly observed when the samples are operated under axial pressure. At the 1st limit, the connection between the stone and the mortar was intact and the masonry sample could maintain its monolithicity. At the 2nd limit, the first capillary cracks start to form in the connecting mortar and this initial crack formation depends on the physical and mechanical properties of the mortar. At the 3rd limit, the size of the crack increases in the loading after the first crack formation, and new cracks start to be formed. Also, at this limit, the sample is separated into vertical strips. These strips separately work with eccentric pressure at external loads, which means the beginning of the rupture of the sample. The initial elasticity module of samples up to $100 \mathrm{~cm}$ in height was $930-1,770 \mathrm{kN} / \mathrm{cm}^{2}$. According to Ref. [19], the initial deformation module $\left(E_{0}\right)$ of samples up to $100 \mathrm{~cm}$ in height are calculated with this equation:

$$
E_{0}=\alpha f_{c, \text { mas }}
$$

where, $f_{c, \text { mas }}$ is the average compressive strength of the masonry; and it can be chosen from Ref. [19] depending on the strength of the masonry stone and mortar. Also, the $f_{c, \text { mas }}$ value can be determined depending on the results of the axial pressure test of the masonry. For samples with a height of $100 \mathrm{~cm}, f_{c, \text { mas }}=$ $1.12 \mathrm{kN} / \mathrm{cm}^{2}$, depending on the experimental research results in this article. $\alpha$ is the elasticity coefficient of the masonry. Depending on Eq. (2):

$$
\alpha=\frac{E_{0}}{f_{c, \text { mas }}}=\frac{1770}{1.12}=1580.36
$$

This value is $5.36 \%$ higher than the value of $\alpha=$ 1,500 selected from Ref. [19] according to the type of masonry used in this study.

The initial deformation modulus $\left(E_{0}=1,770 \mathrm{kN} / \mathrm{cm}^{2}\right)$ value determined based on experimental research results is used to calculate the load impact on masonry under the impact of a small number of variable repetitive loads with the equation:

$$
E=0.5 E_{0}
$$

The vibration period and stiffness of the masonry building when the rubble stone masonry building's elements made of different materials (concrete) can be determined with the elasticity module:

$$
E=0.8 E_{0}
$$

In non-linear calculations of proportional deformations of buildings masonry constructions under 
short-time loading impact:

$$
\varepsilon=-\frac{1.1}{\alpha} \ln \left[1-\frac{\sigma}{1.1 f_{c, \text { mas }}}\right]
$$

the formula above can be used [19]. In addition, the shear modulus value of rubble stone masonry constructions can be considered as:

$$
\mathrm{G}=0.4 \mathrm{E}_{0}=0.4 \times 1,770=708 \mathrm{kN} / \mathrm{cm}^{2}
$$

If the height is greater than $100 \mathrm{~cm}$, the behavior character of the samples can be examined in the 4th limit state. At the 1 st limit state, the connection between the stone and the wall does not deteriorate and the sample continues to carry load without any cracks in the sample. At the 2nd limit state, capillary cracks start to form on the vertical edges of the sample and the masonry sample begins to separate into two layers with increasing load. At the 3rd limit state, the masonry sample starts to work like a two-layered wall. At the 4th limit state, the sample is separated into separate vertical strips. The $\varepsilon-N / N_{K}$ relationship of these samples determined by the results of experiments is given in Fig. 14.

Samples up to $100 \mathrm{~cm}$ in height exhibited higher strength and monolithic behavior. It has been concluded that the tensile-deforming behavior of samples up to $100 \mathrm{~cm}$ in height in the experiments performed is most appropriate for earthquake-resistant building construction. Strength of earthquake resistant walls can be increased by making walls in $100 \mathrm{~cm}$ sections and considering reinforced concrete beams between these sections. For this reason, continuous reinforced concrete beams must be used in the transverse and longitudinal direction of the entire building walls, every $100 \mathrm{~cm}$ of wall height in rubble stone walled bearing systems. These beams prevent the walls from dividing into layers under load, allow the building's transverse and longitudinal walls to work together, and prevent separation of the transverse and longitudinal walls of the building at the intersections. The constructive formation of such walls is shown in Fig. 9.

\section{Experimental Investigation of Strength and Deformation of Limestone Masonry}

Absheron peninsula of Azerbaijan is a region rich in limestones which can be used as walls. The unit weight of these stones is less than $1,800 \mathrm{~kg} / \mathrm{m}^{3}$ and the compressive strength is between $5 \sim 15 \mathrm{~N} / \mathrm{mm}^{2}$. Many buildings built in ancient times were made with stones obtained by cutting these stones in standard sizes and in certain shapes. Temples from the fire-worshiping period in Azerbaijan as well as many buildings such as church and mosques from the later periods that survived and are still used as museums, churches and mosques were built with these stones. Today, people have improved the methods of cutting and using these stones. After the second half of the twentieth century, the technique of cutting these limestones in standard sizes of $(190 \times 190 \times 390)$ has begun to be applied. A two-row masonry system has been developed with the aid of these standard sized stones. Subsequent studies have revealed that the potential strength capacity of the stone in the two-row masonry system is not fully utilized [20, 21]. In 1960, scientists began to think about increasing the masonry resistance by changing the geometric dimensions of the cut stone and switching to a one-row masonry system instead of a two-row masonry system. Cemal Eyyubov and Salman Fataliyev from Azerbaijan Construction Materials Research Institute proposed to cut the limestone (300x300x130) $\mathrm{mm}$ in size and to make the walls in a single row with a thickness of $300 \mathrm{~mm}$ [22]. Experimental studies to determine the initial elastic modulus $\left(E_{0}\right)$, elasticity coefficient $(\alpha)$ values and axial compressive resistance of these stone braids are given below.

\subsection{Investigation of Mechanical Properties of} Masonry Samples under Axial Pressure

\subsubsection{Experimental Investigation Method of} Mechanical Properties of Masonry Samples under Axial Pressure 
The test samples were prepared in two series. The first series of samples were used to determine the mechanical properties of the masonry and the second series of samples were used to examine the behavior of the masonry under axial pressure. The first series of samples were prepared as $300 \times 300 \mathrm{~mm}$ in cross section and $830 \mathrm{~mm}$ in height, while the second series of samples were $300 \times 1,200 \mathrm{~mm}$ in cross section and $1,130 \mathrm{~mm}$ in height. The limit value of ratio of the height of masonry samples to cross-sectional dimensions is assumed as less than 4 preparing it like a short column [19]. In the first series of samples prepared for the experiment, the true value of this ratio was 2.8 and in the second series of samples, it was 3.8. This allows the test samples to work like short columns during the experiment. The constructive formations of the test samples are shown in Figs. 16a and 16b, and the pre-experimental appearances are given in Fig. 16c.

All of these samples were made by stones cut from the same stone pit and using masonry mortar (sand-cement mixture) prepared in the same mixture. The experimentally determined compressive strength of the masonry stones is $1.53 \mathrm{kN} / \mathrm{cm}^{2}$ and the tensile strength is $0.154 \mathrm{kN} / \mathrm{cm}^{2}$. The tensile strength of the stone samples is determined by the results of the splitting test of the stones. The cube strength of the cement mortar was determined to be $0.86 \mathrm{kN} / \mathrm{cm}^{2}$ at 70x70x70 mm

The tests of the samples were carried out on PSU-500 branded hydraulic press. The upper and lower loading axes of the press were placed on the same straight line passing through the center of gravity of the cross section of the sample (centering of the samples) with the aid of clock-type indicators placed on the 4 sides of the test samples. During the test, loading was made in steps corresponding to $10 \%$ of the distributor load value of the sample. Deformations were measured for each loading step from the trussed clock-type indicators on the sample. Vertical and horizontal deformations were measured separately during the test. The measurement error of the manometer for the experiments is measured as $1 \% \sim 2 \%$, and the indicators

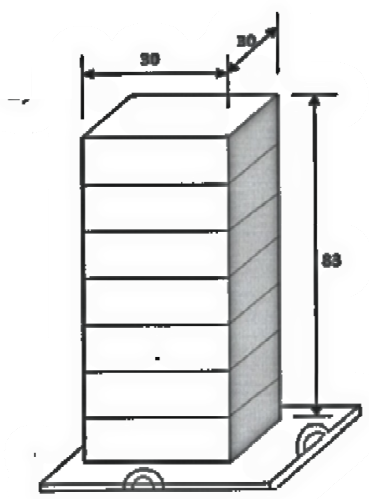

(a)
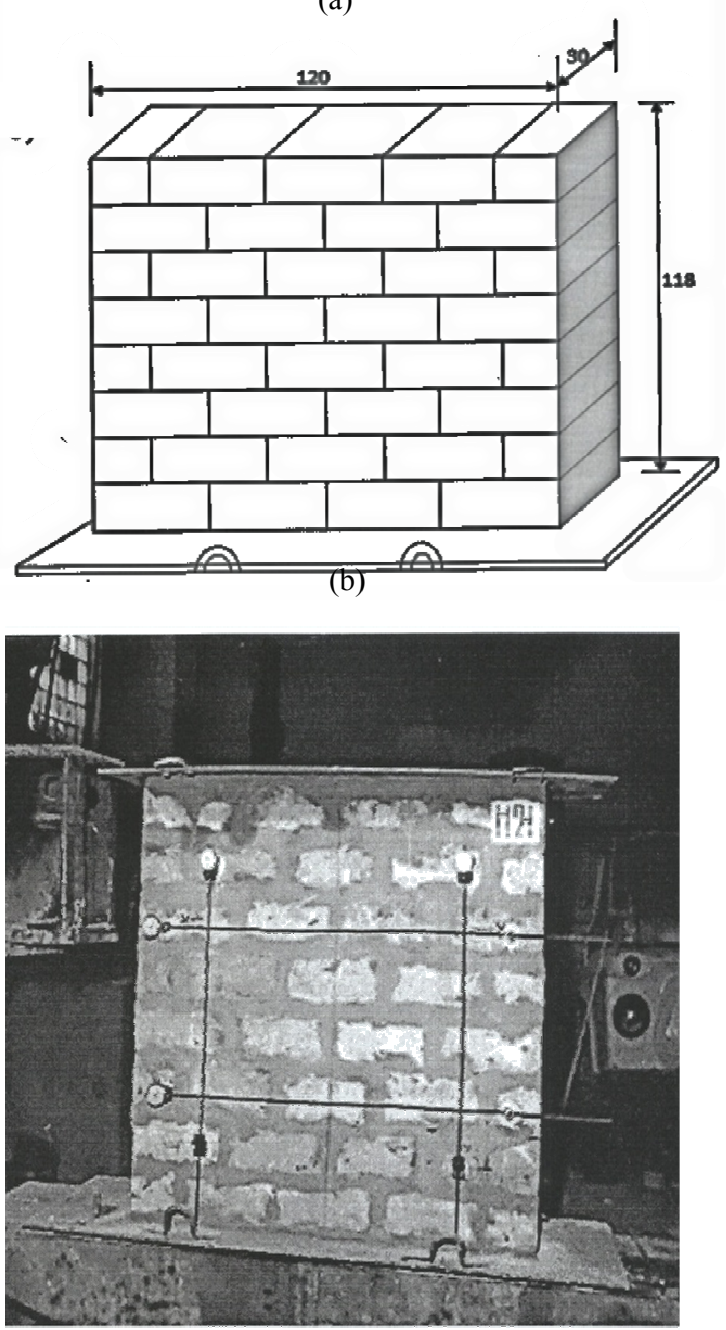

(c)

Fig. 16 Construction of the masonry samples: (a) column sample; (b) wall sample; (c) pre-experimental view of sample. 


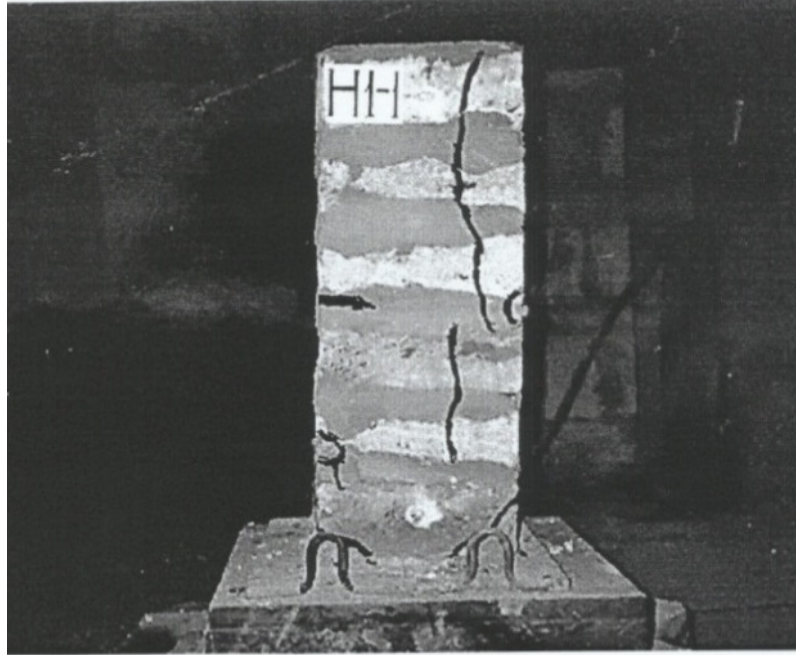

(a)

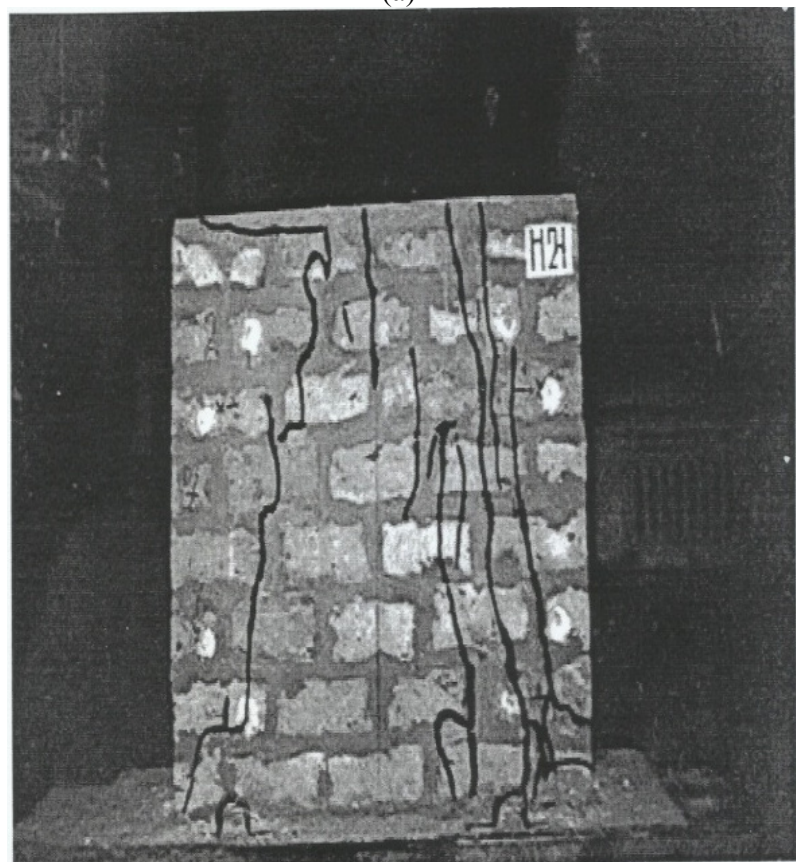

(b)

Fig. 17 Cracking characters of test samples: (a) 1st crack formation character of serial samples; (b) 2nd crack formation character of serial samples.

measure the deformations in the error range of $0.01 \sim 0.001$. Thus, it can be assumed that the error rate in the experiments is below $2 \%$. The layout of the deformation measuring devices on the test samples is given in Fig. 16c.

3.1.2. Results of Experimental Investigation of Masonry Samples under Axial Pressure

The cracking characteristics of the serial samples are shown in Fig. 17a, and the post-experimental view of the samples prepared for the series is given in Fig. 17b. As a result of examining the cracking characters of the samples, it has been shown that the cracked planes of the experimented samples are developed by incorporating the stone cross-sections.

The mechanical properties of the masonry samples determined according to the experimental research results are given in Table 1. From the analysis of the results given in this table, it is revealed that the results of the experiments in the same level are not very different from each other. For this reason, the placement of the masonry stones in the direction of high strength is due to the preparation of the samples one by one and having the strengths of the masonry stones are close to each other.

According to the cutting technique of the stone, $130 \mathrm{~mm}$ size of the stones of $300 \times 300 \times 130 \mathrm{~mm}$ is the direction with the greatest strength; therefore, the stones will work in the direction of high strength in masonry regardless of the working character of the sample. Since this improves the homogeneity of the masonry, no significant difference is observed between the results of different samples.

As can be seen from the diagram $E, N / N_{\mathrm{k}}$ given in Fig. 18, the graph of the ratio of the load value $(N)$ according to the loading step to the distributor load value $\left(N_{d}\right)$ up to the limit of $0.65 \sim 0.70\left(E ; N / N_{k}\right)$ develops close to the linear character. This permits the transition coefficient to the calculation resistance $\left(f_{d, \text { mas }}\right)$ from the average compressive strength limit $\left(f_{c, \text { mas }}\right)$ of the determined masonry as $K=1.4 \sim 1.5$ according to Ref. [19]. In addition, $K$-value recommended in Ref. [19] was assigned for the two-row masonry system. In the study conducted in this article (Table 1), the test results of single-row knitting system samples were obtained as $12 \% \sim 13 \%$, different from each other for the same series. Therefore, $K=1.12 \sim 1.13$ is possible. For design applications, $K$ value can be rounded to $K=1.2$.

Thus, according to Ref. [19], in masonry with 300x300x130 mm sized type stones, when the stone 
Table 1 Comparison of mechanical properties of masonry samples obtained with experiments and calculations test results of the first series of Samples 2: test results of the second series of samples.

\begin{tabular}{|c|c|c|c|c|c|c|c|c|c|c|c|c|c|}
\hline \multirow{3}{*}{$\begin{array}{l}\text { Serial } \\
\text { No. }\end{array}$} & \multirow{3}{*}{$\begin{array}{l}\text { Sample } \\
\text { No. }\end{array}$} & \multirow{3}{*}{$\begin{array}{l}\text { Geometric } \\
\text { measurements and } \\
\text { cross-section areas } \\
\text { of samples }\left(\mathrm{cm}^{2}\right)\end{array}$} & \multicolumn{2}{|c|}{$\begin{array}{c}\text { Strength of } \\
\text { sample material }\end{array}$} & \multicolumn{2}{|c|}{ Rupture limit } & \multicolumn{2}{|c|}{$\begin{array}{l}\text { Compressive } \\
\text { resistance of } \\
\text { samples } \\
\end{array}$} & \multicolumn{5}{|c|}{ Mechanical properties of the masonry } \\
\hline & & & \multirow[b]{2}{*}{ Stone } & \multirow[b]{2}{*}{$\begin{array}{l}\text { Masonry } \\
\text { mortar }\end{array}$} & \multirow[b]{2}{*}{$\begin{array}{l}\text { For each } \\
\text { sample }\end{array}$} & \multirow[b]{2}{*}{$\begin{array}{l}\text { Average } \\
\text { value }\end{array}$} & \multirow[b]{2}{*}{$\begin{array}{l}\text { For each } \\
\text { sample }\end{array}$} & \multirow[b]{2}{*}{$\begin{array}{l}\text { Average } \\
\text { value }\end{array}$} & \multirow[b]{2}{*}{$\begin{array}{l}E_{0} \\
\left(\mathrm{~kg} / \mathrm{cm}^{2}\right)\end{array}$} & $\alpha$ & $\mu$ & $\alpha$ & $\mu$ \\
\hline & & & & & & & & & & \multicolumn{2}{|c|}{$\begin{array}{l}\text { Obtained from } \\
\text { the } \\
\text { experiments }\end{array}$} & \multicolumn{2}{|c|}{$\begin{array}{l}\text { Obtained } \\
\text { from the } \\
\text { calculations }\end{array}$} \\
\hline \multirow{2}{*}{ I } & 1 & $30 \times 30 \times 83$ & \multirow{2}{*}{153} & \multirow{2}{*}{86} & 48.8 & \multirow{2}{*}{52.15} & 54.2 & \multirow{2}{*}{57.93} & \multirow{2}{*}{102,500} & \multirow[t]{2}{*}{1891} & 2.35 & 2,141 & 4.3 \\
\hline & 2 & A-900 & & & 55.5 & & 61.67 & & & & 1.86 & 2,059 & 3.82 \\
\hline \multirow{2}{*}{ II } & 1 & $30 \times 120 \times 113$ & \multirow{2}{*}{153} & \multirow{2}{*}{86} & 199 & \multirow{2}{*}{204.5} & 55.28 & \multirow{2}{*}{56.8} & - & - & - & 2,128 & 4.23 \\
\hline & 2 & A-3,600 & & & 210 & & 58.32 & & - & - & - & 2,095 & 4.03 \\
\hline \multicolumn{3}{|c|}{ Average values } & & & & & & & 102,500 & 1,891 & 2.1 & 2,106 & 4.1 \\
\hline
\end{tabular}

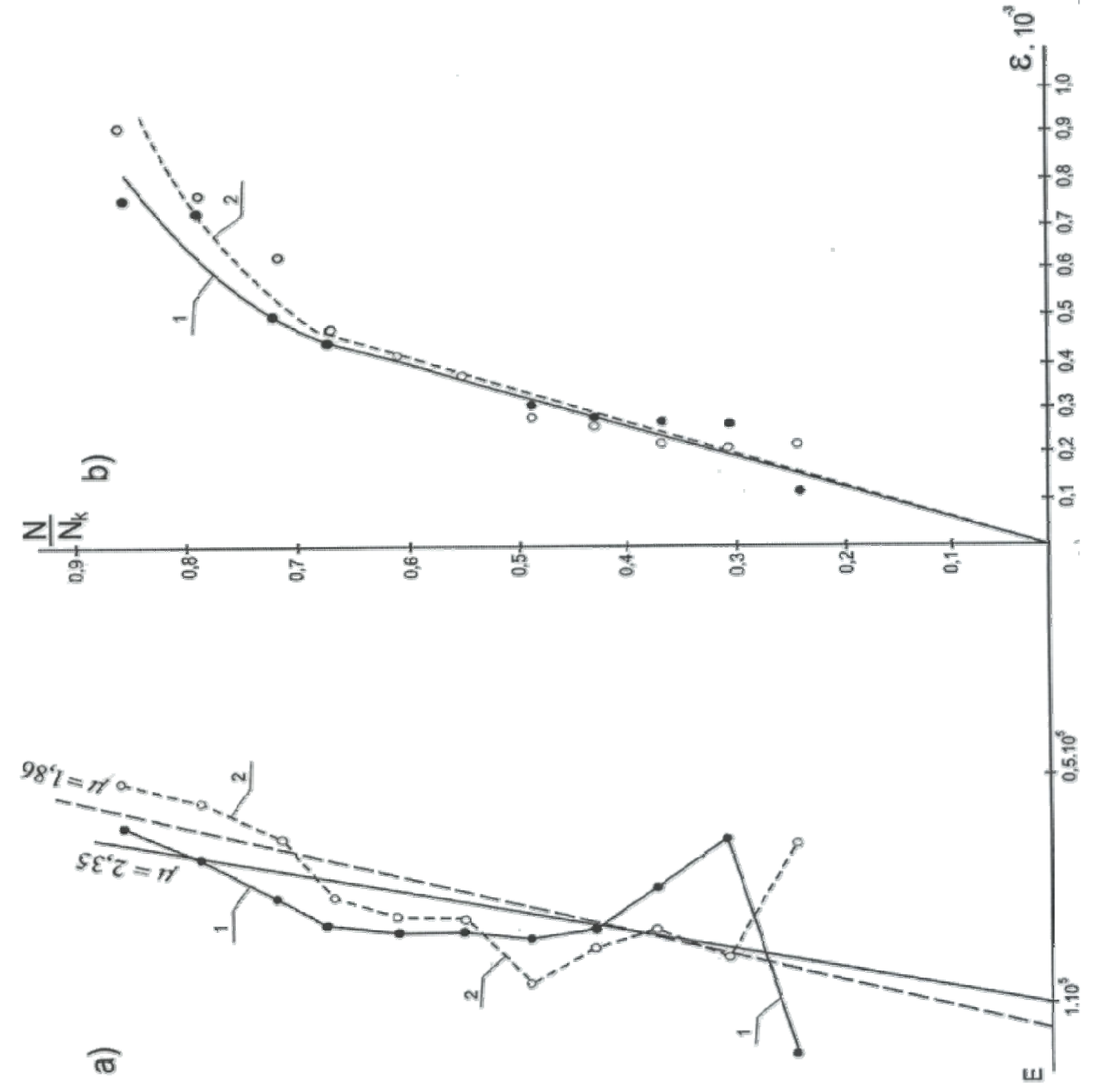

Fig. 18 The dependence between the elasticity module and $N / N_{k}$ calculated on the basis of the test results: (a) $E, N / N_{k}$ graph; (b) $\varepsilon, N /{ }_{\mathrm{Nk}}$ graph. 


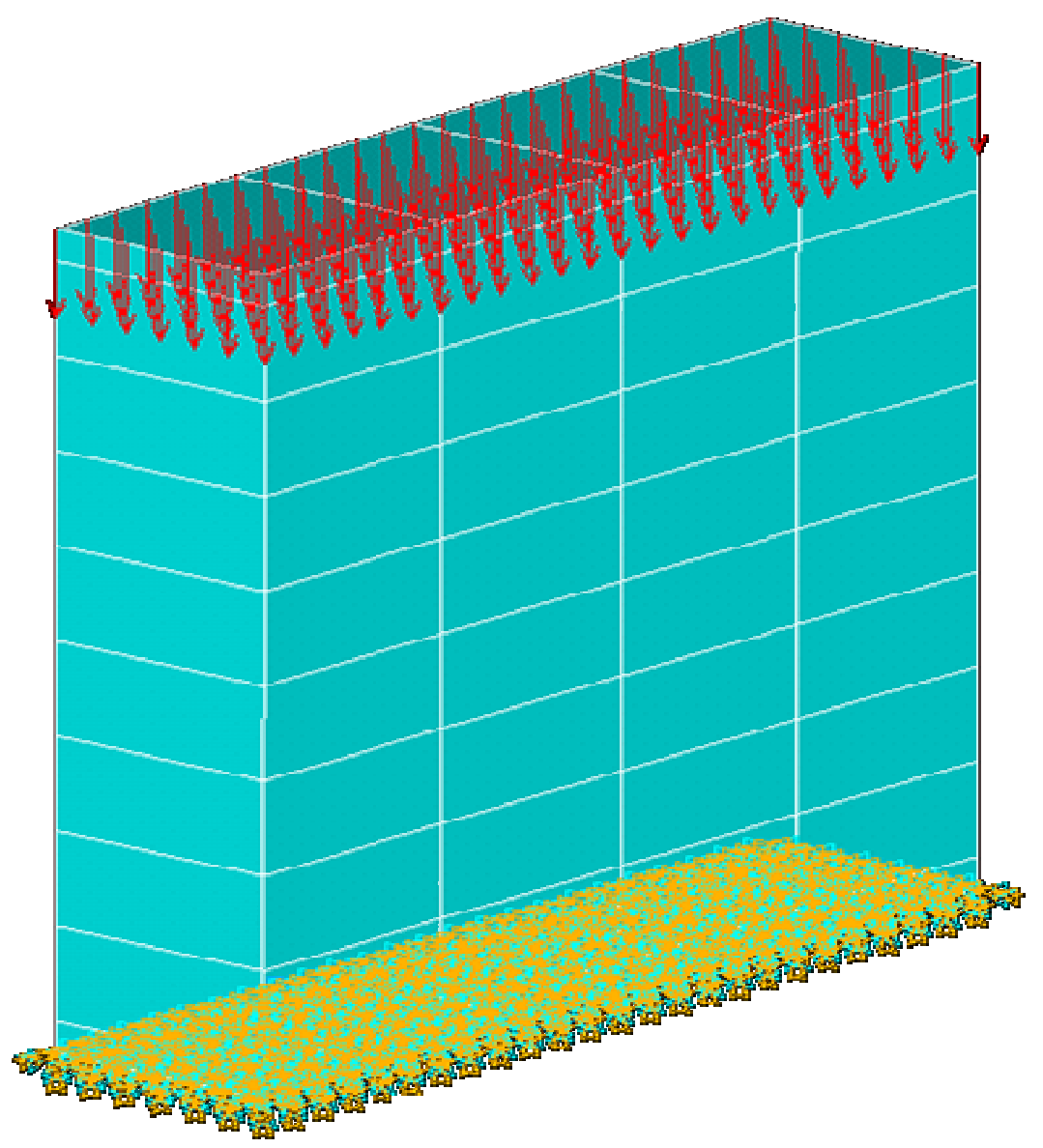

Fig. 19 Finite element model.

strength is $1.53 \mathrm{kN} / \mathrm{cm}^{2}$ and the mortar strength is 0.86 $\mathrm{kN} / \mathrm{cm}^{2}$ :

When $K=1.5$,

$$
f_{d, \text { mas }}=\frac{f_{c, \text { mas }}}{K}=\frac{0.57933}{1.5}=0.386 \mathrm{kN} / \mathrm{cm}^{2}
$$

When $\mathrm{K}=1.4$,

$$
f_{d, \text { mas }}=\frac{0.57933}{1.4}=0.414 \mathrm{kN} / \mathrm{cm}^{2} \text {. }
$$

Thus, according to Ref. [19], $f_{d, \text { mas }}=(0.386 \sim 0.414)$ $\mathrm{kN} / \mathrm{cm}^{2}$ can be accepted.

When the calculation design strength of the masonry system made with single row is taken as $K=1.2$ according to the test results

$f_{d, \text { mas }}=\frac{0.57933}{1.2}=0.48 \mathrm{kN} / \mathrm{cm}^{2}$ the formula above may apply.

According to Eurocode 6,

$f_{c, \text { mas }}=a f_{c, s t}^{b} . f_{c, \text { mo }}^{c}$ can be calculated [23].

$f_{c, s t}=$ stone compression strength, $f_{c, m o}=$ mortar compression strength, $\mathrm{a}=$ classification coefficient depending on the material and can be accepted as $a=$ 0.40 [24].

$b, c=$ volumetric ratios of stone and mortar can be accepted as $b=0.75, c=0.25$ [24].

$f_{c, \text { mas }}=0.4 f_{c, s t}^{0.75} f_{c, \text { mo }}^{0,25}=52,98 \mathrm{~kg} / \mathrm{cm}^{2}$ is different in $8.55 \%$ from experimental result.

The link between the modulus of elasticity and $N / N_{d}$ obtained from the experiment results is shown in Fig. $18 \mathrm{a}$ and the tensile-deformation curves are shown in Fig. 18b. The links given in Fig. 18 are prepared by S.A. Semetsov method [25]. It was observed that the difference between the elasticity coefficient obtained from the experiments and the elasticity coefficient calculated theoretically did not exceed $11 \%$. According to the test results on the first series of samples, the average load carrying capacity of the samples was $521.5 \mathrm{kN}$, the average strength was $0.579 \mathrm{kN} / \mathrm{cm}^{2}$, the 
initial elasticity modulus was $1,025 \mathrm{kN} / \mathrm{cm}^{2}$, the modulus of elasticity was 1,891 and the plasticity coefficient $(\mu)$ was 2.1 .

According to the results of the tests performed on the second series of samples, the average load carrying capacity of the samples was $2,045 \mathrm{kN}$ and the average strength was $0.568 \mathrm{kN} / \mathrm{cm}^{2}$. It was observed that the average strengths of the second series of samples were $1.8 \%$ lower than the first series of samples. As the geometric sizes of the sample increase, the fact that the sample is difficult to homogeneously work against the external forces can be explained as the fact that the tension that occurs under the load is not distributed uniformly to the sample. The curve $\left(N / N_{k}-\varepsilon\right)$ changes linearly up to $N / N_{k}=0.7$ from $\left(N / N_{k}-\varepsilon\right)$ graph given in Fig. $18 \mathrm{~b}$ and it is possible to assume that the calculation strength is $70 \%$ of the rupture strength.

\subsubsection{Result of Numerical Study}

Masonry wall was modelled by using homogenization technic of composite material with ANSYS finite element program (Fig. 19). Stone and mortar represents with solid 65 element without reinforcement. Experimental values were assigned the elements. Maximum compressive strength of masonry was $0.45 \mathrm{kN} / \mathrm{cm}^{2}$ obtained.

\section{Conclusions}

The results of the investigation of the earthquake behaviors of rural buildings constructed from local materials and the results of experimental studies on wall samples made from different materials can be summarized as follows.

Although the destruction of buildings with bearing systems made of local materials due to earthquakes is widespread, there are many examples of buildings constructed using mechanical properties of these materials surviving destructive earthquakes damage-free or in a less damaged state.

The use of clay-straw mixture as a filler material in the wood carcass spaces causes the dynamic impact of the earthquake on the building to be lightened and makes the wooden carcass significantly increase its earthquake load bearing capacity. Cross-ties may not be used in wooden carcass.

The adherence stress between the rubble stones and the cement mortar varies depending on the strength of the mortar. The mean value of the adherence stress was $0.15 \mathrm{~N} / \mathrm{mm}^{2}$ when the mortar strength was $2.4 \mathrm{~N} / \mathrm{mm}^{2}$; $0.36 \mathrm{~N} / \mathrm{mm}^{2}$ when the mortar strength was $4.8 \mathrm{~N} / \mathrm{mm}^{2}$ and $0.4 \mathrm{~N} / \mathrm{mm}^{2}$ when the mortar strength was $6.3 \mathrm{~N} / \mathrm{mm}^{2}$.

Compressive strength of samples prepared at $1.0 \mathrm{~m}$ height with rubble stones was $(0.8 \sim 1.0) \mathrm{kN} / \mathrm{cm}^{2}$, and their initial modulus of elasticity was $93 \sim 177 \mathrm{kN} / \mathrm{cm}^{2}$.

It was observed that the wall samples prepared as $1.00 \mathrm{~m}$ in height with rubble stones had high strength and the subsequent increase of the sample height caused decrease of sample strength. For walls constructed with rubble stones, the limit value can be assumed as $1.00 \mathrm{~m}$. In order to obtain walls with maximum strength at the desired height, continuous reinforced concrete beams must be used throughout the building walls, with a cross section of $h \times 0.10 \mathrm{~m}(h=$ wall thickness) at every $1.00 \mathrm{~m}$ and with $2 \varnothing 12$ longitudinal reinforcement. The stirrups of reinforcement mat (transverse reinforcement rods) can be formed from reinforcing bars of $\Phi 8$ at every $200 \mathrm{~mm}$. These buildings can be built in earthquake zones without using vertical beams.

In the experimental research carried out on the wall samples obtained by limestone masonry prepared by cutting the stones in $(0.30 \times 0.30 \times 0.13) \mathrm{m}$ standard dimensions, the strength of the masonry made with stones with the strength of $15.3 \mathrm{~N} / \mathrm{mm}^{2}$ and mortar with the strength of $8.6 \mathrm{~N} / \mathrm{mm}^{2}$ can be assumed as $5.8 \mathrm{~N} / \mathrm{mm}^{2}$; initial modulus of elasticity as 10,250 $\mathrm{N} / \mathrm{mm}^{2}$ and elasticity coefficient as 1,891 . Limestones produced by being cut in $(0.30 \times 0.30 \times 0.13) \mathrm{m}$ standard size can be used directly in one to three-storey structures, and as an infilled wall element in multi-storey structures.

According to ANSYS analysis results, masonry 
compression strength was $0.45 \mathrm{kN} / \mathrm{cm}^{2}$ obtained. Numerical analysis result is $22.4 \%$ different from experimental results.

Depending on the test results, the transition coefficient for the masonry samples from the compressive strength limit to the calculation strength is $K=1.2$ and the calculated compressive strength of this masonry is $R=0.48 \mathrm{kN} / \mathrm{cm}^{2}$.

\section{References}

[1] R SNIP II 7-81. 1982. Basics of Construction and Design in Seismic Zones. Moscow.

[2] Kuliyev, Q. T., Gasanov, A. G., Agamirzoyev, R. A., and Eyyubov, D. G. 1984. Idrismaillinckiyezemletryaseniya. B kwzemletryaseniya SSSR 1981 Godunauka. Moskva: Soviet Union Academy of Science. (in Russian)

[3] Eyyubov, C. H. 1988. Inşaatın Kalitesi ve Depremler. Bakü: Azerneşir. (in Turkish)

[4] Bayındırlık ve İskan Bakanlığı İnşaat Mühendisleri Odası, Ankara-İzmir. 1975. Afet Bölgelerinde Yapılacak Yapılar Hakkında Yönetmelik. (in Turkish)

[5] Bayındırlık ve İskan Bakanlığı TMMOB İnşaat Mühendisleri Odas1. 2007. Deprem Bölgelerinde Yapılacak Binalar Hakkında Yönetmelik. (in Turkish)

[6] Eyyubov, C. H. 1978. Binaların Deprem Dayanıklılı̆̆ı. Bakü: Azerneşir. (in Turkish)

[7] Geybullayev, G. R., Eyyubov, J. G., and Eminbeyli, T. Z. 1990. "Engineering Analysis of the Azerbaijan SSR the Period of 1961-1981." In Proceedings of the Ninth European Engineering, Vol. 9. Moscow.

[8] Richter, C. F. 1958 Elementary Seismology. San Francisco: W. H. Freeman and Company.

[9] Eyyubov, J. G. 1992. "The Investigation of the Design Reinforcement of the Wall Masonry of an Earthquake Proof Rural Building of Local Material of Azerbaijan." In Proceedings of the 12th Russian-Chines Regional Seminar on P S Earthquake Resistance Construction, 113-21, Moskow.

[10] Eyyubov, C., Geybullayev, G., and Eyyubov, İ. 2000. "Behavior of Structural Systems Made of Local Materials During Earthquakes." Presented at 4th International Congress on Advances in Civil Engineering. Gazimagusa, KKTC. (in Turkish)

[11] Eyyubov, C., Uğur, Y., and Eyyubov, İ. 2003. "Earthquake Resistance of Building Made of Local Materials." Presented at Earthquake and Planning Technical Congress Proceedings Book, Vol. 1, İstanbul. (in Turkish)

[12] Eyyubov, C., Uğur, Y., Koçak, A., and Eyyubov, İ. 2006. "Behavior of Structures Made of Local Materials During
Destructive Earthquake.” Presented at 7th International Congress on Advances in Civil Engineering. Proceedings Book, İstanbul. (in Turkish)

[13] Eyyubov, C. H., Akpınar, F., and Budak A. 1993. "Experimental Investigation of Earthquake Resistance of Carcass Bulding Depending on Infill Wall Construction." Presented at "Congress on Advances in Civil Engineering I" Vol. 1. Gazimagusa, KKTC. (in Turkish)

[14] Eyyubov, D. G. 1981. Analizposledstviy Ismaillinskogo Zemletryaseniya. Ekspress Informasiya Seriya 14. StroitelstvoiArxitektura, Stroitelstvo Osobix Usloviyax, Seysmostoykoye Stroitelstvo Vipusk 12. Moskva: Construction Committee Publishing House. (in Russian)

[15] Korçinskiy, İ. L., and Polyakov S.V. 1961. Building Design Principles in Seismic Zones. Moscow: Construction Committee Publishing House.

[16] Homman, C. V., and Burridge, L. W. 1939. "Reinforced Brickwork." Journal of Structural Engineering, April.

[17] Eyyubov, D. G., Orucov, M. F., Xudavercliyeva, X. İ, and Abdurahmanova, L. R. 1991. Isledovaniye Proçnostii Deformativnosti Kladki Sten Selskix Zdaniy Novoy Konstruksiiiz Reçnogoi Rvannogo Kamnya. Tem. Sb. Nauçnix Trudov Azgosproekt AzNḯSA. Baku: Construction and Architecture Institute Publications. (in Russian)

[18] Polyakov, S. V. 1973. .Knitting Construction Made of Limestone, Kişinyov. Moskva: Construction Committee Publishing House. (in Russian)

[19] SNIP II-22-81. 2012, Aktualizirovannaya Redaksiya, Kamenniyei Armokamenniye Konstruksii. SP 1.13330.2012 Moskva: Ministerstvo Regionalnogo Razvitiya Rossiyckoy Fedarasii. (in Russian)

[20] Eyyubov, C., Yılmaz, C., and Altun, F. 1997. "Binaların Onarımı ve Depreme Dayanıklılığının Takviye Yöntemlerinin İncelenmesi (Investigation of Repair and Strengthening Methods of Buildings)." Presented at 3rd Congress on Advances in Civil Engineering. Proceedings Book Vol. 2. Ankara. (in Turkish)

[21] Eyyubov., C., Babayev, Z., and Murat, İ. 2002. "Investigation of Behavior of Structural Masonry Limestone Walls under the Influence of Vertical and Horizontal Loads." Presented at 5th International Congress on Advances in Civil Engineering, İstanbul. (in Turkish)

[22] F ataliyev, S. A., Eyyubov, C. H., and Eyyubov, İ. C. 1998. Investigation of Behavior of Limestone Masonry Wall under the Influence of Axial Pressure. Report AZIME, Bakü. (in Turkish)

[23] Eurocode 6. 2005. Design of Masonry Structures Part 1-1: General Rules for Reinforced and Unreinforced Masonry Structures.

[24] Proske, D., and Gelder, P. 2009. Safety of Historical Stone 
Arch Bridges. New York: Springer, 180-3.

[25] Semetsov, S. A. 1962. Selection of Logarithmic Link
Between Stress and Deformation Based on Experimental Research Results. Moscow. 